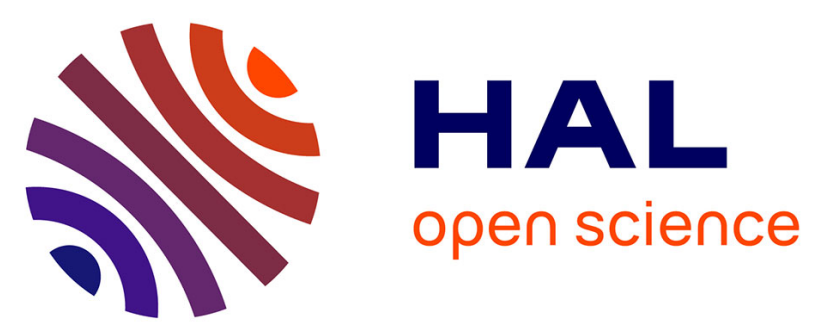

\title{
Release of phenolic acids from sunflower and rapeseed meals using different carboxylic esters hydrolases from Aspergillus niger
}

Oscar Laguna, Elise Odinot, Alexandra Bisotto, Bruno Barea, Pierre Villeneuve, Jean-Claude Sigoillot, Eric Record, Craig Faulds, Frédéric Fine, Laurence Lesage-Meessen, et al.

\section{To cite this version:}

Oscar Laguna, Elise Odinot, Alexandra Bisotto, Bruno Barea, Pierre Villeneuve, et al.. Release of phenolic acids from sunflower and rapeseed meals using different carboxylic esters hydrolases from Aspergillus niger. Industrial Crops and Products, 2019, 139, pp.111579. 10.1016/j.indcrop.2019.111579 . hal-02474040

\author{
HAL Id: hal-02474040 \\ https://hal.science/hal-02474040
}

Submitted on 11 Feb 2020

HAL is a multi-disciplinary open access archive for the deposit and dissemination of scientific research documents, whether they are published or not. The documents may come from teaching and research institutions in France or abroad, or from public or private research centers.
L'archive ouverte pluridisciplinaire HAL, est destinée au dépôt et à la diffusion de documents scientifiques de niveau recherche, publiés ou non, émanant des établissements d'enseignement et de recherche français ou étrangers, des laboratoires publics ou privés. 
Crops and Products

Elsevier Editorial System(tm) for Industrial

Manuscript Draft

Manuscript Number: INDCRO-D-19-01468R1

Title: Release of phenolic acids from sunflower and rapeseed meals using different carboxylic esters hydrolases from Aspergillus niger

Article Type: Research Paper

Section/Category: Biorefinery, valorization of byproducts

Keywords: rapeseed and sunflower meals; Aspergillus niger; chlorogenate esterase; feruloyl esterase; sinapic acid; caffeic acid

Corresponding Author: Dr. Jérôme LECOMTE, Ph.D.

Corresponding Author's Institution: CIRAD

First Author: Oscar LAGUNA, Ph.D.

Order of Authors: Oscar LAGUNA, Ph.D.; Elise ODINOT, Ph.D.; Alexandra BISOTTO, Ph.D.; Bruno BAREA, B.Sc.; Pierre VILLENEUVE, Ph.D.; Jean-Claude SIGOILLOT, Ph.D.; Eric RECORD, Ph.D.; Craig B FAULDS, Ph.D.; Frédéric FINE, Ph.D.; Laurence LESAGE-MEESSEN, Ph.D.; Anne LOMASCOLO, Ph.D.; Jérôme LECOMTE, Ph.D.

Abstract: Sunflower and rapeseed meals are agro-industrial coproducts that contain high amount of phenolics (1-4 \% dry matter), mostly as esters of caffeic acid (CA) and sinapic acid (SA), respectively. The enzymatic hydrolysis of the ester bonds enables to recover the corresponding free phenolic acids that are bioactive compounds and platform molecules for various applications in green chemistry. Here we aimed to find the best route for producing free CA and SA by applying various fungal carboxylic ester hydrolases from recombinant Aspergillus niger strains either directly on crude meal or on their phenolic extracts obtained by methanolic extraction. Two types of meals were studied: industrial (commercial) meals (I-meals), produced by a process that includes cooking at $95-100^{\circ} \mathrm{C}$ and steam desolventizing at $105-107^{\circ} \mathrm{C}$, and (ii) non-industrial meals (NI-meals) obtained at pilot-scale with much milder heat treatment, that offer a higher total phenolic content. CA release through hydrolysis of sunflower meal (SFM) was successfully achieved with A. niger type-B feruloyl esterase (AnFaeB) and chlorogenic acid esterase (ChlE). Maximal amount of free CA released was of $54.0 \pm$ 1.1 to $59.8 \pm 2.1 \mathrm{\mu mol} / \mathrm{g}$ defatted dry matter (DDM) from I-SFM (94-100\% hydrolysis yield) against $42.0 \pm 1.1$ to $52.3 \pm 0.2 \mu \mathrm{mol} / \mathrm{g}$ DDM (59-73응 hydrolysis yield) from NI- SFM in which CA release was hampered by a phenolic oxidation side-reaction, seemingly due to meal endogenous polyphenol oxidase activities. AnFaeB and ChlE hydrolysis of phenolic extracts from NI-SFM increased the CA amount obtained to 55.0-68.1 $\mu \mathrm{mol} / \mathrm{g}$ DDM (77-95\% hydrolysis yield). In all cases, AnFaeB showed broader specificity towards SFM caffeoyl quinic acid isomers than ChlE. In particular, ChlE did not hydrolyze 3-0-caffeoylquinic acid. The maximal amount of free SA released by AnFaeA hydrolysis was $41.3 \pm 0.3 \mu \mathrm{mol} / \mathrm{g} \mathrm{DDM}$ from NI-SFM (50\% hydrolysis yield) and $32.3 \pm 0.4 \mu \mathrm{mol} / \mathrm{g}$ DDM from the phenolic extract (64\% hydrolysis yield), with AnFaeA also having sinapine 
transesterification activity that led to the synthesis of 1,2-di-0-

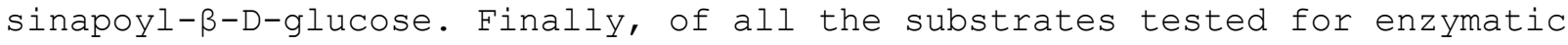
hydrolysis in our conditions, I-RSM and NI-SFM extract showed the best compromise between initial total phenolic content, hydrolysis yields and amounts of CA/SA released. 
- Aspergillus niger AnFaeA efficiently released free sinapic acid from rapeseed meal

- A. niger AnFaeB and ChlE efficiently released free caffeic acid from sunflower meal

- Enzymatic hydrolysis performed on methanolic extracts avoided phenolics degradation

- AnFaeA acyl transferase activity on sinapine led to 1,2-di- $O$-sinapoyl- $\beta$-D-glucose

- Non-thermally-treated meals had the advantage of high initial phenolic contents 
Manuscript

1 Release of phenolic acids from sunflower and rapeseed meals using different

4 Oscar Laguna $^{\mathrm{a}, \mathrm{d}}$, Elise Odinot ${ }^{\mathrm{b}}$, Alexandra Bisotto $^{\mathrm{b}}$, Bruno Baréa $^{\mathrm{a}, \mathrm{d}}$, Pierre Villeneuve $^{\mathrm{a}, \mathrm{d}}$,

5 Jean-Claude Sigoillot $^{\mathrm{b}}$, Eric Record ${ }^{\mathrm{b}}$, Craig B. Faulds ${ }^{\mathrm{b}}$, Frédéric Fine ${ }^{\mathrm{c}}$, Laurence

6 Lesage-Meessen ${ }^{\mathrm{b}}$, Anne Lomascolo $^{\mathrm{b}}$ and Jérôme Lecomte ${ }^{\mathrm{a}, \mathrm{d}^{*}}$

7

8

\section{carboxylic esters hydrolases from Aspergillus niger}

\section{${ }^{a}$ CIRAD, UMR IATE, F-34398 Montpellier, France}

${ }^{\mathrm{b}}$ INRA, Aix Marseille Univ, UMR1163 BBF, Biodiversité et Biotechnologie

Fongiques, 163 avenue de Luminy, 13288 Marseille cedex 09, France

${ }^{\mathrm{c}}$ TERRES INOVIA, F-33600, Pessac, France

${ }^{\mathrm{d}}$ IATE, Univ Montpellier, CIRAD, INRA, Montpellier SupAgro, Montpellier, France

\section{Abstract}

Sunflower and rapeseed meals are agro-industrial coproducts that contain high amount of phenolics (1-4\% dry matter), mostly as esters of caffeic acid (CA) and sinapic acid (SA), respectively. The enzymatic hydrolysis of the ester bonds enables to recover the corresponding free phenolic acids that are bioactive compounds and platform molecules for various applications in green chemistry. Here we aimed to find the best route for producing free CA and SA by applying various fungal carboxylic ester hydrolases from recombinant Aspergillus niger strains either directly on crude meal or on their phenolic extracts obtained by methanolic extraction. Two types of meals were studied: (i) industrial (commercial) meals (I-meals), produced by a process that includes cooking at $95-100^{\circ} \mathrm{C}$ and steam desolventizing at $105-107^{\circ} \mathrm{C}$, and (ii) non-industrial

${ }^{*}$ Corresponding author at: Supagro-INRA, Bâtiment 33, 2 Place Pierre Viala, 34060 Montpellier Cedex 2, France. E-mail: jerome.lecomte@cirad.fr 
meals (NI-meals) obtained at pilot-scale with much milder heat treatment, that offer a higher total phenolic content. CA release through hydrolysis of sunflower meal (SFM) was successfully achieved with A. niger type-B feruloyl esterase (AnFaeB) and chlorogenic acid esterase (ChlE). Maximal amount of free CA released was of $54.0 \pm$ 1.1 to $59.8 \pm 2.1 \mu \mathrm{mol} / \mathrm{g}$ defatted dry matter (DDM) from I-SFM (94-100\% hydrolysis yield) against $42.0 \pm 1.1$ to $52.3 \pm 0.2 \mu \mathrm{mol} / \mathrm{g}$ DDM (59-73\% hydrolysis yield) from NISFM in which CA release was hampered by a phenolic oxidation side-reaction, seemingly due to meal endogenous polyphenol oxidase activities. AnFaeB and ChlE hydrolysis of phenolic extracts from NI-SFM increased the CA amount obtained to 55.0-68.1 $\mu \mathrm{mol} / \mathrm{g}$ DDM (77-95\% hydrolysis yield). In all cases, AnFaeB showed broader specificity towards SFM caffeoyl quinic acid isomers than ChlE. In particular, ChlE did not hydrolyze 3-O-caffeoylquinic acid. The maximal amount of free SA released by AnFaeA hydrolysis was $41.3 \pm 0.3 \mu \mathrm{mol} / \mathrm{g}$ DDM from NI-SFM (50\% hydrolysis yield) and $32.3 \pm 0.4 \mu \mathrm{mol} / \mathrm{g}$ DDM from the phenolic extract (64\% hydrolysis yield), with AnFaeA also having sinapine transesterification activity that led to the synthesis of 1,2-di- $O$-sinapoyl- $\beta$-D-glucose. Finally, of all the substrates tested for enzymatic hydrolysis in our conditions, I-RSM and NI-SFM extract showed the best compromise between initial total phenolic content, hydrolysis yields and amounts of $\mathrm{CA} / \mathrm{SA}$ released.

Keywords: rapeseed and sunflower meals, Aspergillus niger, chlorogenate esterase, feruloyl esterase, sinapic acid, caffeic acid

\section{Abbreviations}

1,2-diSG: 1,2-di-O-sinapoyl- $\beta$-D-glucose

3-CQA: 3-O-Caffeoylquinic acid 
Manuscript

51 3,4-diCQA: 3,4-di-O-caffeoylquinic acid

52 3,5-diCQA: 3,5-di-O-caffeoylquinic acid

53 4-CQA: 4-O-Caffeoylquinic acid

54 4,5-diCQA: 4,5-di-O-caffeoylquinic acid

55 5-CQA: 5-O-Caffeoylquinic acid

56 A. niger: Aspergillus niger

57 ACE: Angiotensin-I Converting Enzyme

58 AnFaeA: A. niger type-A feruloyl esterase

59 AnFaeB: A. niger type-B feruloyl esterase

60 CA: Caffeic acid

61 CAE: Caffeic acid equivalents

62 CAEsters: Caffeic acid esters

63 ChlE: Chlorogenic acid esterase

64 DDM: Defatted dry matter

65 DM: Dry matter

66 HPLC: High performance liquid chromatograph

67 I: Industrial

68 I-meals: Industrial meals

69 I-RSM: Industrial rapeseed meal

70 I-SFM: Industrial sunflower meal

71 MBTH: 3-methyl-2-benzothiazolinonehydrazone

72 MOPS: 3-( $N$-morpholino)propanesulfonic acid

73 nkat: nanokatal

74 NI: Non-industrial

75 NI-meals: Non-industrial meals

76 NI-RSM: Non-industrial rapeseed meal 
Manuscript

NI-SFM: Non-industrial sunflower meal

PPO: Polyphenol oxidase

RSM: Rapeseed meal

SA: Sinapic acid

SAE: Sinapic acid equivalents

SAEsters: Sinapic acid esters

SFM: Sunflower meal

SNP: Sinapine

TCAD: Total caffeic acid derivatives

TPC: Total phenolic compounds

TSAD: Total sinapic acid derivatives

\section{Introduction}

Rapeseed (Brassica napus L.) and sunflower (Helianthus annuus L.) are two of the most important oilseed crops in the world (Lomascolo et al., 2012) and their oils are mainly used for human consumption or for biofuel production (Borredon et al., 2011; Fine et al., 2015). Rapeseed (RSM) and sunflower (SFM) meals are the main coproducts of the seed pressing and de-oiling processes. In 2018, worldwide production of RSM and SFM was estimated at 39.2 Mt and 21.0 Mt respectively (http://www.indexmundi.com/agriculture/). They are mostly dedicated to animal feed because of their high protein content with about $38 \mathrm{~g} / 100 \mathrm{~g}$ dry matter (DM) and 28 g/100 g DM for RSM and SFM respectively (González-Pérez and Vereijken, 2007; Ivanova et al., 2016; Ugolini et al., 2015). In addition, studies have shown that these raw materials can also serve as a source of protein isolates with bioactive properties, such as Angiotensin-I Converting Enzyme (ACE) inhibitory activities, antioxidant or antithrombotic activities, and bile acid-binding capacities (Aider and Barbana, 2011; 


\section{Manuscript}

103 Campbell et al., 2016; Ugolini et al., 2015). These protein isolates also possess

emulsification and foaming properties and are considered as promising ingredients for industrial non-food applications such as adhesives and detergents, among others (Fetzer et al., 2018, 2019). Moreover, RSM and SFM can also be used as substrates in microbial fermentative processes like saccharification and production of enzymes, antibiotics and other bioproducts (for a review, see Lomascolo et al., 2012). Also, as outlined in the work of Licata et al. (2019), these meals represent a potential source of energy production through combustion processes or biogas production and could be considered as economically convenient in a short agro-energy chain.

RSM and SFM also have relatively high total phenolic compound (TPC) contents, ranging from 1-2 $\mathrm{g} / 100 \mathrm{~g}$ DM for RSM and 2-4 g/100 $\mathrm{g}$ DM for SFM. These phenolics are almost exclusively sinapic acid esters (SAEsters) in RSM, with sinapine as the main derivative ( $80 \%$ of the TPC content) and the remaining $20 \%$ composed of mono-, diand tri-sinapoyl esters of sugars and/or kaempferol (Baumert et al., 2005; Milkowski and Strack, 2010; Siger et al., 2013). In SFM, phenolics are mostly found as caffeic acid esters (CAEsters). 5-Caffeoylquinic acid (chlorogenic acid) is the major phenolic compound accounting for $70 \%$ of the TPC content, while the remaining $30 \%$ are other mono- and di-caffeoylquinic acids, as well as coumaroyl- and feruloylquinic acids. Free caffeic (CA) acid is also found in SFM but accounts for just $0.5 \%$ of the TPC content (Guo et al., 2017; Szydłowska-Czerniak et al., 2011; Weisz et al., 2009).

Phenolic acids, particularly hydroxycinnamic acids, are bioactive molecules with interesting properties that include antioxidant (Gullón et al., 2018; Shahidi and Ambigaipalan, 2015), anti-inflammatory (Oueslati et al., 2012) and antimicrobial (Ouerghemmi et al., 2017) activities among others. These bioactive properties can be enhanced by modifying the hydrophilic/hydrophobic balance of the molecules (Laguerre et al., 2013; Lecomte et al., 2010; Szydłowska-Czerniak et al., 2018). For 


\section{Manuscript}

example, esterification with aliphatic alcohols of adequate chain-length improved their antioxidant activity in liposome suspensions, oil-in-water emulsions (Laguerre et al., 2010; Sørensen et al., 2015) and even in cultured cells, as well as their bactericidal activity on selected bacteria (Suriyarak et al., 2013). This phenomenon, related to the so-called "cut-off effect", was attributed to a better location and concentration of esters at the interfacial membrane where lipid oxidation occurs (Laguerre et al., 2011; McClements and Decker, 2018), and to their ability to cross or interact with membranes of living cells and microorganisms. Moreover, owing to their particular structure and reactivity, phenolic acids (i.e. hydroxybenzoic and hydroxycinnamic acids), as their corresponding vinyl phenols, have gained much importance during the last decade for the synthesis of new sustainable polymers and pre-polymers (Aouf et al., 2012; DiotNéant et al., 2017; Pion et al., 2014; Reano et al., 2015; Wang et al., 2011; Zago et al., 2015a). So any raw material and process enabling large-scale production and recovery of phenolic acids would positively facilitate the development of these sustainable active platform molecules and polymers. In this context, SFM and RSM, which are cheap, abundant, and rich in phenolics, make perfectly suitable candidates. It is worth noting that only few studies have reported the use of these two raw materials for the production of phenolic acids and derivatives like vinyl phenols (Kreps et al., 2014; Odinot et al., 2017).

Microbial cinnamoyl and feruloyl esterases are carboxylic ester hydrolase enzymes (EC 3.1.1) that are able to hydrolyze ester linkages between hydroxycinnamic acids and sugars present in plant cell-walls (Faulds, 2010) with various in vivo specificities according to type of enzyme and origin of microorganism. For instance, the type-A feruloyl esterase from the filamentous fungus Aspergillus niger (called AnFaeA) is highly active on sinapic and ferulic acid methyl esters and on some 1,5-esterified feruloylated oligomers from cereals. Type-B feruloyl esterase from A. niger (so called 


\section{Manuscript}

AnFaeB) is rather active on caffeic and $p$-coumaric acid methyl esters and on some 1,2and 1,6-esterified feruloylated oligomers from sugar-beet pulp (Brézillon et al., 1996; Faulds and Williamson, 1994). Another type of A. niger carboxylic ester hydrolase, called chlorogenic acid hydrolase (or chlorogenate esterase, ChlE) was primarily found to be highly specific to chlorogenic acid (5-O-caffeoylquinic acid) hydrolysis (Benoit et al., 2007). Historically, pure AnFaes were shown to be essentially inactive when used directly on natural raw substrates. However, we recently studied the enzymatic hydrolysis of an industrial rapeseed meal (I-RSM) using a recombinant AnFaeA to produce sinapic acid (Odinot et al., 2017) and demonstrated that this enzyme was highly effective on the raw RSM. In the best conditions, AnFaeA hydrolyzed most of the SAEsters present in the RSM, with an overall yield of 68-76 \% (100\% hydrolysis of sinapine).

Taking this previous work forward, here we aimed to find the best route and operating conditions for producing free CA and SA by applying various fungal carboxylic ester hydrolases from recombinant Aspergillus niger strains either directly on crude meal or on their phenolic extracts obtained by methanolic extraction. Two types of meals were studied: (i) I-meals (industrial meals), produced by a process that includes cooking at $95-100^{\circ} \mathrm{C}$ and steam desolventizing at $105-107^{\circ} \mathrm{C}$, and (ii) NI-meals (custom-made non-industrial meals), obtained at pilot-scale with much milder heat treatment. In a general way, the NI-meals have a net higher phenolic content than the corresponding I-meals (Zago et al., 2015b). We first studied the hydrolysis of sunflower meals (NI-SFM and I-SFM) with two types of fungal ester hydrolases and determined the best conditions for caffeic acid (CA) production. Exploiting their hydrolytic activity on CAEsters (Faulds, 2010; Gopalan et al., 2015; Ramos-de-la-Peña and ContrerasEsquivel, 2016), we tested an A. niger type-B recombinant feruloyl esterase (AnFaeB) and a recombinant $A$. niger chlorogenate esterase (ChlE) on the SFMs. To the best of 
our knowledge, these two enzymes have never been used on oilseed meals. Enzymatic hydrolysis was also performed on methanolic extracts from NI-SFM which are mainly composed of phenolics, minerals, and carbohydrates (Sripad and Narasinga Rao, 1987) but are devoid of the proteins and other meal constituents. Then, the same approach was applied to a non-industrial rapeseed meal (NI-RSM) and the corresponding phenolic extract, by using AnFaeA to release free SA. The results (hydrolysis yield and highest released SA amount) were compared with our previous data obtained on an I-RSM (Odinot et al., 2017). All cases were compared and discussed based on the following parameters: hydrolysis yields, qualitative and quantitative composition of hydrolyzed hydroxycinnamoyl esters, and free CA or SA amount released per gram of substrate.

\section{Materials and Methods}

\subsection{Chemicals}

Sinapine thiocyanate (99.0\% HPLC) was isolated from rapeseed meal according to the method outlined by Mailer (2008). 3,4-di- $O$-caffeoylquinic, 3,5-di- $O$ caffeoylquinic and 4,5-di- $O$-caffeoylquinic acids (>99.0\% HPLC) were isolated from yerba mate leaves, following the procedure previously described in Tong et al. (2015). Sinapic acid (98\%) was from AlfaAesar (Karlsruhe, Germany). 4- and 5-caffeoylquinic (chlorogenic) acids (95\%), caffeic acid (>98\%), methanol and water (both HPLC grade, $>99.9 \%), \mathrm{NaOH}(>97 \%)$ and MOPS (3-(N-morpholino)propanesulfonic acid) buffer were purchased from Sigma-Aldrich (Saint-Quentin-Fallavier, France). ACS grade ethyl acetate $(>99,5 \%)$ was purchased from Honeywell Riedel-de-Haën (Seelze,

Germany)

\subsection{Plant materials}

\subsubsection{Preparation of the non-industrial sunflower and rapeseed meals (NI-SFM} and NI-RSM) 
NI-SFM and NI-RSM were prepared at OLEAD oilseed-protein crops

207

208

209

210

211

212

213

214

215

216

217

218

219

220

221

222

223

224

225

226

227

228

229

230

technology platform's pilot oilseed plant (Pessac, France), according to the following methods. Whole sunflower (Helianthus annuus L.) seeds (75 kg) were first cold flaked in a flaker (Damman-Croes N.V., Roeselare, Belgium) equipped with two smooth 500 mm-diameter contra-rotating cylinders spaced at $0.3 \mathrm{~mm}$ (capacity: $200 \mathrm{~kg} \cdot \mathrm{h}^{-1}$ ). Whole rapeseed (Brassica napus L.) seeds $(120 \mathrm{~kg}$ ) were first cold pressed on a MBU20 screw press (OLEXA®, Feuchy, France), fed at $75 \mathrm{~kg} \cdot \mathrm{h}^{-1}$ of seeds, to remove $75 \%$ of the initial oil amount. The residual oil from the sunflower or rapeseed press cakes was further extracted by steeping in hexane at $50^{\circ} \mathrm{C}$, in a $480 \mathrm{~L}$-capacity Guedu Pilot Agitated Filter Dryer (De Dietrich Process Systems, Semur, France). Extraction was performed on $73 \mathrm{~kg}$ of each press cake by immersion in hexane for $15 \mathrm{~min}$ followed by filtration. Five or six successive immersion-filtration steps were required to remove the oil from the SFM and RSM, respectively. The defatted meals were then desolventized in the same device, under vacuum at $60^{\circ} \mathrm{C}$ and without steam injection. Then, the meals obtained were finely ground by a high-shear impact mill (Hosokawa-alpine, type UPZ100, Augsburg, Germany) using a 0.1-mm (for NI-RSM) or a 0.5-mm (for NISFM) grid operated at room temperature at a speed of $18,000 \mathrm{rpm}$, and a feeder speed of $4 \mathrm{~kg} \cdot \mathrm{h}^{-1}$.

\subsubsection{Industrial sunflower and rapeseed meals (I-SFM and I-RSM)}

I-SFM and I-RSM were provided by the Technical Centre for Oilseed Crops, Grain Legumes and Industrial Hemp (Terres Inovia, Pessac, France). I-SFM and I-RSM were obtained from seed pressing and hexane solvent oil extraction. Further industrial processing steps included: preconditioning at about $45^{\circ} \mathrm{C}$, cooking at $95-100^{\circ} \mathrm{C}$ for 60 min, then steam desolventizing at $107 \pm 2^{\circ} \mathrm{C}$ for $80 \pm 5 \mathrm{~min}$ in the case of I-RSM or 105 $\pm 2^{\circ} \mathrm{C}$ for $50 \pm 5 \mathrm{~min}$ in the case of I-SFM. 
Manuscript

\subsection{Enzyme production}

The extracellular recombinant feruloyl esterase A (AnFaeA), feruloyl esterase B (AnFaeB) and chlorogenate esterase (ChlE) were produced, respectively, by the recombinant strains A. niger BRFM451, A. niger BRFM766 and A. niger BRFM891, formerly obtained in our Laboratory of Fungal Biodiversity and Biotechnology (UMR1163 BBF, Marseille, France), by genetic engineering of the host strain A. niger D15\#26, as previously described (Benoit et al., 2007; Levasseur et al., 2004; Record et al., 2003). Briefly, in this study, these strains were used to produce batches of AnFaeA, AnFaeB and ChlE, respectively, in a culture medium containing (per liter contents): glucose $50 \mathrm{~g}, \mathrm{NaNO}_{3} 5.95 \mathrm{~g}, \mathrm{KCl} 0.52 \mathrm{~g}, \mathrm{MgSO}_{4} \cdot 7 \mathrm{H}_{2} \mathrm{O} 0.49 \mathrm{~g}$, and $1 \mathrm{~mL}$ of trace elements (1000× stock, per liter: $\mathrm{ZnSO}_{4} \cdot 7 \mathrm{H}_{2} \mathrm{O} 21.85 \mathrm{~g}, \mathrm{H}_{3} \mathrm{BO}_{3} 11 \mathrm{~g}, \mathrm{MnCl}_{2} \cdot 4 \mathrm{H}_{2} \mathrm{O} 4.95$ $\mathrm{g}, \mathrm{FeSO}_{4} \cdot 7 \mathrm{H}_{2} \mathrm{O} 5 \mathrm{~g}, \mathrm{CoCl}_{2} \cdot 6 \mathrm{H}_{2} \mathrm{O} 1.69 \mathrm{~g}, \mathrm{CuSO}_{4} \cdot 5 \mathrm{H}_{2} \mathrm{O} 1.6 \mathrm{~g}, \mathrm{Na}_{2} \mathrm{MoO}_{4} \cdot 2 \mathrm{H}_{2} \mathrm{O} 1.5 \mathrm{~g}$, EDTA-Na $2 \cdot 2 \mathrm{H}_{2} \mathrm{O} 64.76 \mathrm{~g}$ ) in a $0.1 \mathrm{M}$ citrate-sodium phosphate buffer at $\mathrm{pH} 5$ (Levasseur et al., 2004).

\subsection{Accession number of protein sequences}

The protein sequences of AnFaeA, AnFaeB and ChlE were registered in the NCBI database under accession numbers CAA70510, AJ309807, and ABK62698, respectively.

\subsection{Enzyme activity assay}

Esterase activity was assayed spectrophotometrically at either $37^{\circ} \mathrm{C}$ and $55^{\circ} \mathrm{C}$ for AnFaeA or $37^{\circ} \mathrm{C}$ and $50^{\circ} \mathrm{C}$ for $\mathrm{AnFaeB}$ and $\mathrm{ChlE}$, as previously described (Odinot $e t$ al., 2017), by monitoring the $\mathrm{A}_{335}$ with respect to the rate of hydrolysis of $0.032 \mathrm{mM}$ of the enzyme substrate in $88 \mathrm{mM}$ of a 3-( $N$-morpholino)propanesulfonic acid (MOPS) buffer (pH 5.5 for AnFaeA and pH6 for AnFaeB and ChlE). The synthetic substrates used were methyl sinapate for AnFaeA, methyl caffeate and methyl $p$-coumarate for AnFaeB, and chlorogenic acid for ChlE. The extinction coefficients at $335 \mathrm{~nm}$ were (in 
Manuscript

$257 \mathrm{~L} \cdot \mathrm{mol}^{-1} \cdot \mathrm{cm}^{-1}$ ): 13,318 for methyl sinapate, 5,500 for sinapic acid, 19,524 for methyl

258 ferulate, 4,409 for ferulic acid, 12,560 for methyl caffeate, 6,060 for caffeic acid, 821

259 for methyl $p$-coumarate, 673 for $p$-coumaric acid and 15,423 for chlorogenic acid.

260 Endogenous polyphenol oxidase (monophenol, $o$-diphenol:oxygen oxidoreductase, EC

261 1.14.18.1) activity was determined in SFM as per a procedure adapted from Halaouli $e t$

262 al. (2005). Five grams of meal were homogenized in $50 \mathrm{~mL}$ sodium phosphate buffer

$263(100 \mathrm{mM}, \mathrm{pH} 6.8)$ at $37^{\circ} \mathrm{C}$ for $3 \mathrm{~h}$ under stirring at $200 \mathrm{rpm}$. After centrifugation at 9500

$264 \times g$ for $40 \mathrm{~min}$, the supernatant was used to assay monophenol oxidase (or cresolase)

265 and diphenol oxidase (or catecholase) activity (Halaouli et al., 2005). Briefly,

266 monophenolase activity was determined in meal extract by monitoring the $\mathrm{A}_{484}$

267 (extinction coefficient 22,300 L.mol${ }^{-1} \cdot \mathrm{cm}^{-1}$ ) with respect to rate of oxidation of $1.25 \mathrm{mM}$

268 L-tyrosine in sodium phosphate buffer $(50 \mathrm{mM}, \mathrm{pH} 6.8)$ at $30^{\circ} \mathrm{C}$, in the presence of 3-

269 methyl-2-benzothiazolinonehydrazone (MBTH, $5 \mathrm{mM}$ ) and L-DOPA using a molar L-

270 DOPA-to-L-tyrosine ratio of 0.057 . Diphenolase activity was determined by monitoring

$271 \quad \mathrm{~A}_{484}$ (extinction coefficient 22,300 L. $\mathrm{mol}^{-1} \cdot \mathrm{cm}^{-1}$ ) with respect to rate of oxidation of 4.2

$272 \mathrm{mM}$ L-DOPA in sodium phosphate buffer $(50 \mathrm{mM}, \mathrm{pH} 6.8)$ at $30^{\circ} \mathrm{C}$, in the presence of 5 273 mM MBTH.

All enzymatic activities were expressed in nanokatals. One nanokatal of activity is defined as the quantity of enzyme that hydrolyzed $1 \mathrm{nmol}$ of substrate per second.

Experiments were performed in triplicate, and the standard deviation was lower than $1 \%$

277 of the mean.

278 2.6. Determination of meal dry matter and lipid contents

Dry matter content of the meals was determined as follow: around two grams

(exactly weighed at $+/-0.01 \mathrm{mg}$ ) of meal were placed into an aluminium capsule 
Manuscript

meal were cooled in a desiccator at room temperature for $30 \mathrm{~min}$ and finally weighed.

The dried matter content was calculated from the difference between the weight of the sample (meal and capsule) before and after drying to constant weight.

Lipid content of the meals was determined by the method previously outlined in the work of Laguna et al. (2018) : Around two grams (exactly weighed at $+/-0.01 \mathrm{mg}$ ) of each fraction were placed into a filter paper envelope previously dried and weighed and the whole was dried at $105{ }^{\circ} \mathrm{C}$ until constant weight. Then, envelopes were extracted with n-hexane for $5 \mathrm{~h}$ using a Soxhlet apparatus. After extraction, envelopes were desolventized at room temperature for 12 hours, dried at $105^{\circ} \mathrm{C}$, then cooled in a desiccator at room temperature for $30 \mathrm{~min}$ and finally weighed. The oil content was calculated from the difference between the dry weight of the sample (meal and envelope) before and after defatting. Values were given as percentage of oil per gram of dry matter.

These two values were taken into account to express other results per gram of dry defatted matter. All experiments were done in triplicate.

\subsection{Methanolic extraction of phenolic compounds from meals}

The extraction of TPC from meal samples was carried out in closed tubes at $75^{\circ} \mathrm{C}$ for $20 \mathrm{~min}$ using a meal-to-methanol ratio of $1: 100(\mathrm{w} / \mathrm{v})$ following the procedure previously described in Laguna et al. (2018). After drying under a nitrogen stream, extracts were kept at $-20^{\circ} \mathrm{C}$ until being processed. All experiments were done in triplicate.

\subsection{Determination of the potentially releasable phenolic acid content in meals}

\section{by alkaline hydrolysis}

Fifty milligrams of meal were mixed with $1.5 \mathrm{~mL}$ of methanol. Then, $6 \mathrm{~mL}$ of 2

$\mathrm{M} \mathrm{NaOH}$ were added to the mixture and incubated at $30^{\circ} \mathrm{C}$ for different times $(15,30$, 60 and $120 \mathrm{~min}$ ). The mixture was then acidified to $\mathrm{pH} 2.0$ using $4 \mathrm{M} \mathrm{HCl}$ with addition 
Manuscript

of $300 \mathrm{mg} \mathrm{NaCl}$ and further extracted three times with ethyl acetate $(2 \mathrm{~mL})$ by stirring for $2 \mathrm{~min}$ at room temperature. After each extraction, samples were centrifugated (3000 $\times g, 5 \mathrm{~min}$ ) and supernatants were collected and pooled. The organic phase was dried under nitrogen stream and the residue was kept at $-20^{\circ} \mathrm{C}$ until HPLC analysis. All experiments were performed in triplicate. The amount of free phenolic acid released from meals after alkaline hydrolysis was used, when possible, as the $100 \%$ baseline reference for the calculations of enzymatic hydrolysis yields.

\subsection{Enzymatic hydrolysis of caffeic acid derivatives in sunflower meals and in}

\section{the corresponding phenolic extracts with AnFaeB and ChIE}

Fifty milligrams of the meal were weighed into a brown flask with a screw cap, and $5 \mathrm{~mL}$ of $100 \mathrm{mM}$ MOPS buffer at $\mathrm{pH} 6$ were added. The closed flasks were incubated in an orbital shaker $(350 \mathrm{rpm})$ at $50^{\circ} \mathrm{C}$ run for $30 \mathrm{~min}$ for homogenization. After this pre-incubation step, two samples (mixture of meal and MOPS buffer) were cooled to $-80^{\circ} \mathrm{C}$ and freeze-dried. Phenolics were then extracted as described in section 2.7, and their content determined and set as $\mathrm{t}=0$. In parallel, different amounts of ChlE and AnFaeB, from 0 to 30 nkat enzyme/g meal, were added to other pre-incubated samples. The hydrolysis assay was run for 10 to $240 \mathrm{~min}$, at $50^{\circ} \mathrm{C}$ and $350 \mathrm{rpm}$. An enzyme-free control was also performed in the same conditions. After the desired treatment duration, the reaction mixture was cooled to $-80^{\circ} \mathrm{C}$ and freeze-dried.

Phenolics were then extracted as described in section 2.7. After drying under a nitrogen stream, extracts were kept at $-20{ }^{\circ} \mathrm{C}$ until HPLC analysis. Two independent trials were performed per experiment.

The enzymatic treatment was also applied to a dry methanolic extract obtained from $50 \mathrm{mg}$ of NI-SFM as described in section 2.7 . Hydrolysis was performed at $50^{\circ} \mathrm{C}$, as described above, on the dry phenolic extract solubilized in $5 \mathrm{~mL}$ MOPS buffer containing $30 \mathrm{nkat} / \mathrm{g}$ meal for AnFaeB or $10 \mathrm{nkat} / \mathrm{g}$ meal for ChlE, respectively. After 
Manuscript

treatment, the reaction medium was cooled to $-80^{\circ} \mathrm{C}$, then freeze-dried and finally extracted as described in section 2.7. After drying under a nitrogen stream, the dry residue was kept at $-20^{\circ} \mathrm{C}$ until HPLC analysis. Two independent trials were performed per experiment.

\subsection{Enzymatic hydrolysis of sinapic acid derivatives in rapeseed meal and in the} corresponding phenolic extracts with AnFaeA

The enzymatic hydrolysis of NI-RSM with AnFaeA was performed in the optimized conditions previously determined on I-RSM by Odinot et al. (2017), with some modifications. Briefly, $50 \mathrm{mg}$ of the meal was weighed into a brown flask with a screw cap and $5 \mathrm{~mL}$ of $100 \mathrm{mM}$ MOPS buffer at pH 5.5 was added. The closed flasks were stirred in an orbital shaker $(350 \mathrm{rpm})$ at $55^{\circ} \mathrm{C}$ run for $30 \mathrm{~min}$ for homogenization. After this pre-incubation step, two samples (mixture of meal and MOPS buffer) were cooled to $-80^{\circ} \mathrm{C}$ and freeze-dried. Phenolics were then extracted as described in section 2.7 and their content determined and set as $\mathrm{t}=0$. In parallel, 39 nkat AnFaeA/g meal was added to other pre-incubated samples. The enzymatic hydrolysis assay was run at $55^{\circ} \mathrm{C}, 350 \mathrm{rpm}$ for 10 to $240 \mathrm{~min}$. An enzyme-free control was also performed in the same conditions. After treatment, the reaction mixture was cooled to $-80^{\circ} \mathrm{C}$ and the mixture was freeze-dried. The methanolic extraction of phenolics was done as described in section 2.7. After drying under a nitrogen stream, extracts were kept at $-20^{\circ} \mathrm{C}$ until HPLC analysis. Two independent trials were performed per experiment. Enzymatic hydrolysis was also applied to a dry NI-RSM methanolic extract obtained from $50 \mathrm{mg}$ of meal as described in section 2.7 . Hydrolysis was performed at $55^{\circ} \mathrm{C}$, as described above, on this dry phenolic extract solubilized in 5 mL MOPS buffer containing 39 nkat AnFaeA/g meal. After treatment, the reaction medium was cooled to $-80^{\circ} \mathrm{C}$, then freezedried and finally extracted as described in section 2.7. After drying under a nitrogen 
Manuscript

stream, the dry residue was kept at $-20^{\circ} \mathrm{C}$ until HPLC analysis. Two independent trials were performed per experiment.

\subsection{High Performance Liquid Chromatography (HPLC) analysis of phenolics}

\section{from hydrolyzed meals}

The dry phenolic extracts, obtained as described in the previous sections, were solubilized in $5 \mathrm{~mL}$ methanol/water $(2 / 1, \mathrm{v} / \mathrm{v})$ and filtered $(0.45-\mu \mathrm{m}$ nylon filter) before HPLC analysis. Phenolic compounds were quantified with an XR UFLC Shimadzu liquid-phase chromatograph equipped with an SPD-M20A diode array detector (Kyoto, Japan). Separation was carried out with an ACE C18 reversed-phase column (5 $\mu \mathrm{m}, 250$ $\mathrm{mm} \times 4.6 \mathrm{~mm}$, Phenomenex, Le Pecq, France). Injection volume, flow rate, and oven temperature were set at $20 \mu \mathrm{L}, 1 \mathrm{~mL} \cdot \mathrm{min}^{-1}$ and $30^{\circ} \mathrm{C}$ respectively. The gradient elution was performed using HPLC-grade water with $0.1 \%$ (v/v) acetic acid (A) and methanol with $0.1 \%(\mathrm{v} / \mathrm{v})$ acetic acid (B) in the following conditions: $15 \% \mathrm{~B}(0-5 \mathrm{~min}), 15-80 \%$ B (5-30 min), 80-100\% B (30-31 min), 100\% B (31-35 min), 100-15\% B (35-40 min).

\subsubsection{Sunflower samples}

Sunflower phenolics were identified according to retention times and quantified at their maximum detection wavelength, as previously described in Laguna et al. (2018). Total caffeic acid derivative (TCAD) content was calculated by summing peak area of all caffeoyl-containing molecules after normalization (i.e. each peak area was divided by the number of caffeoyl moiety contained in the corresponding molecule) and expressed in $\mu \mathrm{mol}$ of caffeic acid equivalent (CAE)/g DDM. CA was selected as external standard and the calibration curve was obtained from series of standard methanolic solutions from 12.5 to $800 \mu \mathrm{M}\left(\mathrm{R}^{2}=0.9991\right)$.

\subsubsection{Rapeseed samples}

SA and sinapine thiocyanate were chosen as external standards for the calibration curves. Their maximum detection wavelength and retention time were 323 
$\mathrm{nm}-17.8 \mathrm{~min}$ and $328 \mathrm{~nm}-11.5 \mathrm{~min}$, respectively. Total sinapic acid derivative (TSAD)

content was calculated by summing peak area of all sinapoyl-containing molecules after normalization (i.e. each peak area was divided by the number of sinapoyl moiety in the corresponding molecule) and expressed in $\mu$ mol of sinapic acid equivalent (SAE)/g

DDM. Calibration curves were obtained from series of standard methanolic solutions from 12.5 to $200 \mu \mathrm{M}$ with $\mathrm{R}^{2}=0.9983$ for sinapic acid and $\mathrm{R}^{2}=0.9987$ for sinapine.

\subsection{Statistical analyses}

Means and standard deviations (SD) were calculated using Minitab Statistical

Software v.18. The means were then compared using one-way ANOVA analysis, with level of significance set to $\alpha=0.05$.

\section{Results and discussion}

\subsection{Characterization of raw materials}

\subsubsection{Moisture, lipid and total phenolic compound contents of the meals}

The moisture and lipid contents of the meals used in this study are shown in Table 1, with values of 7-13\% DM and 1.4-1.9\% DM, respectively. These data were consistent with the values available in the literature (Lomascolo et al., 2012).

\section{Table 1 (suggested location)}

The TPC initially present in SFM and RSM samples, as determined after methanolic extraction, are shown in Table 2 and Table 3 respectively. The TPC content of SFM samples, which was expressed as TCAD content as $95 \%$ of SFM phenolics were found as caffeic acid esters (Karamać et al., 2012; Weisz et al., 2009), was $71.7 \pm 0.5 \mu \mathrm{mol}$ TCAD/g DDM for NI-SFM and 57.4 $\pm 1.5 \mu \mathrm{mol}$ TCAD/g DDM for I-SFM. These data were consistent with the values available in the literature (Baumert et al., 2005; Cai and Arntfield, 2001; Weisz et al., 2009). The TPC content of RSM samples, which was 
expressed as TSAD content as $98 \%$ of their phenolics were shown to be sinapic acid esters (Khattab et al., 2010; Siger et al., 2013), was 64.2 $\pm 1.2 \mu \mathrm{mol}$ TSAD/g DDM for NI-RSM and $44.8 \pm 0.2 \mu$ mol TSAD/g DDM for I-RSM. Thus, TPC content was $1.2-$ to 1.4-fold higher in NI-meals than I-meals, in our conditions.

A mild alkaline treatment $\left(\mathrm{NaOH} 2 \mathrm{M}, 30^{\circ} \mathrm{C}, 30 \mathrm{~min}\right)$ was applied to NI-SFM and ISFM samples in order to determine their respective total releasable CA content (CAEsters in soluble form and potentially bound to the lignocellulosic matrix (Shahidi and Yeo, 2016)), to be taken as reference. Unfortunately, no CA was recovered (Table 2) from either NI-SFM or I-SFM despite the mild alkaline treatment used. Indeed, the high chemical reactivity of CA make it prone to autoxidation at high $\mathrm{pH}$ due to its catechol function that rapidly reacts with $\mathrm{NaOH}$ and oxidizes in the presence of reactive oxygen species (Wildermuth et al., 2016). Thus, as alkaline hydrolysis was not suitable for assessing the total potentially releasable CA from SFM, all calculations and comparisons between various enzymatic hydrolysis conditions were made on the basis of TCAD content after methanolic extraction, expressed as $\mu$ mol CAE/g DDM, and determined from the values of $71.7 \pm 0.5 \mu \mathrm{mol}$ CAE/g DDM for NI-SFM and $57.4 \pm 1.5$ $\mu$ mol CAE/g DDM for I-SFM (Table 2). These values were taken as $100 \%$ reference for the calculations of enzymatic hydrolysis yields.

Table 2 (suggested location)

As done for SFM samples, the total amount of SA initially present in rapeseed meals as soluble conjugates and potentially releasable forms was determined after alkaline hydrolysis. The result was $62.5 \pm 1.8 \mu \mathrm{mol} / \mathrm{g}$ DDM for NI-RSM and $46.8 \pm 3.0 \mu \mathrm{mol} / \mathrm{g}$ DDM for I-RSM (Table 3). These values were not significantly different from those of the initial TSAD content of each meal $(64.2 \pm 1.2 \mu \mathrm{mol} \mathrm{SAE} / g$ DDM for NI-RSM and 
$44.8 \pm 0.2 \mu \mathrm{mol} \mathrm{SAE} / \mathrm{g}$ DDM for I-RSM), indicating that all the sinapic esters from the meal were hydrolyzed and recovered after our alkaline hydrolysis protocol. The latter values, which represented the total amount of potentially releasable SA per gram of DDM, were set as the $100 \%$ reference and used for the calculations of enzymatic hydrolysis yields. Unlike the significant loss of phenolics observed by Vuorela et al. after alkaline hydrolysis of RSM with a $4 \mathrm{M} \mathrm{NaOH}$ solution at $37^{\circ} \mathrm{C}$ for $4 \mathrm{~h}$ (Vuorela et al., 2003), the milder conditions ( $\left.\mathrm{NaOH} 2 \mathrm{M}, 30^{\circ} \mathrm{C}, 30 \mathrm{~min}\right)$ implemented here managed to not degrade the SA and its derivatives.

\section{Table 3 (suggested location)}

\subsubsection{Characterization of meal phenolic composition}

This study identified the phenolic compounds present in the I-SFM by HPLC-

DAD. As shown by HPLC analysis of I-SFM methanolic extract (Fig. 1), the main phenolic compounds were CAEsters such as mono- and di-caffeoylquinic acids, the most abundant being 4- $O$-caffeoylquinic acid (4-CQA) and 5-O-caffeoylquinic acid (5CQA). These two compounds co-eluted and were named chlorogenic acid. Other minor phenolics were 3-O-caffeoylquinic acid (3-CQA), two di-caffeoylquinic acid (di-CQA) isomers (3,5- and 4,5-di- $O$-caffeoylquinic acids), 5- $O$ - $p$-coumaroylquinic acid, 5- $O$ feruloylquinic acid, and CA. These results were in good agreement with other studies (Karamać et al., 2012; Weisz et al., 2009), and were comparable to the NI-SFM composition previously determined by Laguna et al. (2018). 0 61 Figure 1 (suggested location) 
Manuscript

Two of our previous studies characterizing the phenolic composition of NI-RSM and IRSM (Laguna et al., 2018; Odinot et al., 2017) showed that RSM phenolics comprised: sinapine, sinapoyl glucopyranoside, sinapic acid, di- and tri-sinapoyl gentiobiosides, disinapoyl glucopyranoside isomer, and sinapoyl keampferol derivatives.

\subsection{Release of free caffeic acid from sunflower meals by A. niger AnFaeB and}

\section{ChlE}

\subsubsection{Enzymatic hydrolysis of I-SFM}

This study selected AnFaeB and ChlE for the hydrolysis of phenolic esters present in SFMs. Numerous studies have already shown that these enzymes can hydrolyze CAEsters in other raw materials such as coffee pulp, apple marc, autoclaved maize bran and sugar-beet pulp (Benoit et al., 2006; Benoit et al., 2007; Faulds, 2010; Gopalan et al., 2015; Ramos-de-la-Peña and Contreras-Esquivel, 2016), but SFM has never yet been investigated. The optimum $\mathrm{pH}$ and temperature of these enzymes established in previous work were set to 6.0 and $50^{\circ} \mathrm{C}$ for synthetic substrates (e.g. methyl sinapate and 5-CQA) (Asther et al., 2005; Benoit et al., 2006).

Given the drastic heat treatment undergone during the production process, it is reasonable to posit that I-SFM was somewhat recalcitrant to enzymatic degradation. We therefore traced the kinetics of hydrolysis of the major phenolic esters in I-SFM and the release of free CA as a function of enzyme amount (Fig. 2). In the presence of 20 to 30 nkat AnFaeB/g meal, all the CAEesters, initially present in I-SFM, were completely hydrolyzed after $1 \mathrm{~h}$ of incubation (Fig.2, Supplementary data Fig. S1). An amount of 5 nkat AnFaeB/g meal failed to completely hydrolyze the phenolics. An amount of 10 nkat AnFaeB/g meal was able to hydrolyze all CAEesters except 3-CQA (Fig. 2). A minimum concentration of $20 \mathrm{nkat} \mathrm{AnFaeB} / \mathrm{g}$ meal was thus required for complete hydrolysis of all phenolics, and the highest free CA content was obtained with 30 nkat AnFaeB/g meal after a $3 \mathrm{~h}$ incubation $(59.8 \pm 2.1 \mu \mathrm{mol} / \mathrm{g}$ DDM $)$, which corresponded to 
a 100\% hydrolysis yield. AnFaeB thus showed high catalytic efficiency on all the mono- and dicaffeoylquinic acid isomers present in I-SFM (Fig. 2), together with the $p$ coumaroyl and feruloyl derivatives (Supplementary data, Fig. S1).

In the presence of ChlE, the hydrolysis of 3,5-diCQA and 4,5-diCQA was complete after $3 \mathrm{~h}$ of incubation whatever the amount of enzyme. Conversely, 3-CQA was not hydrolyzed at all in any condition, even though 4-CQA and 5-CQA were 90\% hydrolyzed after $2 \mathrm{~h}$ of incubation with ChlE (Fig. 2). The highest free CA content of obtained from I-SFM with ChlE was $54.0 \pm 1.1 \mu \mathrm{mol} / \mathrm{g}$ DDM after $2-4 \mathrm{~h}$ incubation with 5-30 nkat enzyme/g meal. Compared to $\mathrm{AnFaeB}$, this slightly lower value of free CA released was mainly due to the inability of ChlE to hydrolyze 3-CQA, which was still found at $6.1 \pm 0.3 \mu \mathrm{mol} \mathrm{CAE} / \mathrm{g}$ DDM whatever the enzyme concentration (Fig. 2, supplementary data Fig. S1).

AnFaeB has already been shown to have a broader specificity than ChlE for hydrolyzing chlorogenic acids from agricultural by-products such as maize bran and sugar-beet pulp (Benoit et al., 2006). For instance, unlike ChlE, AnFaeB was found to hydrolyze 5-O-p-coumaroylquinic acid and feruloylated oligomers (Benoit et al., 2007). This confirmed the decisive role of the moieties adjacent to the ester bond for correct alignment of the substrate in the active site of Faes. To the best of our knowledge, there is no literature data on the relative activity of AnFaeB and ChlE against the different mono- and di-caffeoylquinic acids. Here, we demonstrated that ChlE showed selectivity for different caffeoylquinic acid isomers in the SFM compared to AnFaeB. The concentrations of 30 nkat $\mathrm{AnFaeB} / \mathrm{g}$ meal and $10 \mathrm{nkat} \mathrm{ChlE} / \mathrm{g}$ meal were then chosen to be further applied on NI-SFM 
Manuscript

\subsubsection{Enzymatic hydrolysis of NI-SFM}

Fig. 3A and Fig. 3B shows the results of enzymatic hydrolysis performed on NISFM with AnFaeB and ChlE, respectively. When AnFaeB was used, all the chlorogenic acid (4- and 5-CQA) was hydrolyzed after $10 \mathrm{~min}$. When ChlE was used, 4- and 5-CQA were $95 \%$ hydrolyzed in our conditions. The highest concentration of free CA released in the reaction medium was observed after $30 \mathrm{~min}$ with AnFaeB $(52.3 \pm 0.2 \mu \mathrm{mol} / \mathrm{g}$ DDM) and ChlE $(42.0 \pm 1.1 \mu \mathrm{mol} / \mathrm{g}$ DDM $)$. However, these values remained lower than the initial concentration of chlorogenic acid of $55.8 \pm 0.9 \mu \mathrm{mol}$ CAE/g DDM in the meal (Table 2). It is worth noting that there was a strong decrease in TCAD content over time (Fig. 3), with or without enzyme (control), resulting in a loss of TCAD compared to the initial content in the meal (Table 2). While the effect of other factors (including $\mathrm{pH}$ and temperature) cannot be totally ruled out, the most likely explanation was the presence of endogenous enzymes in the NI-SFM that degraded CA and its derivatives during the pre-incubation and incubation steps. Studies have already demonstrated the presence of polyphenol oxidase (PPO) in sunflower meal and its high activity on chlorogenic acid (Wildermuth et al., 2016). Therefore, although our hydrolysis conditions $\left(\mathrm{pH} 6.0,50^{\circ} \mathrm{C}\right.$ ) did not exactly correspond to PPO optimum $\mathrm{pH}$ and temperature $\left(7.5\right.$ and $45^{\circ} \mathrm{C}$ respectively; Wildermuth et al., 2016), we found it reasonable to posit that the residual PPO activity was sufficient to continuously oxidize chlorogenic acid and related compounds from the pre-incubation step. Here we measured PPO activity in endogenous SFM meal extracts and found $1.02( \pm 0.08)$ nkat $/ \mathrm{mL}$ diphenol oxidase activity and $0.43( \pm 0.02) \mathrm{nkat} / \mathrm{mL}$ monophenol oxidase activity, which are characteristic of a tyrosinase-type activity (Halaouli et al., 2005). In addition, it is noteworthy that 15 putative PPO-encoding gene sequences were predicted in the publicly-available Helianthus annuus genome from the NCBI Database 
540 (https://www.ncbi.nlm.nih.gov/search/all/?term=polyphenol+oxidase+helianthus+annuu

541 s).

ChlE), the maximal amount of CA released from NI-SFM remained lower than that

AnFaeB, and $42.0 \pm 1.1 \mu \mathrm{mol} / \mathrm{g}$ DDM versus for $54.0 \pm 1.1 \mu \mathrm{mol} / \mathrm{g}$ DDM for ChlE).

Thus, it seemed that the heat treatment (cooking at $95-100^{\circ} \mathrm{C}$ followed by steam endogenous enzymes in the SFM even if this heat treatment was also responsible for a significant decrease in TPC (Table 2). This constituted a major drawback that greatly limited the value of non-thermally-treated NI-SFM as a substrate for in situ enzymatic production of CA.

\subsection{AnFaeB and ChlE hydrolysis of NI-SFM methanolic extract} after a sequence of methanolic extraction, drying, and solubilization in reaction buffer. Methanol mainly extracted phenolic compounds, minerals and carbohydrates from the meal (Sripad and Narasinga Rao, 1987), but not the proteins, including the possible endogenous enzymes responsible for the degradation of phenolics. Fig. 4A shows the fast hydrolysis of CAEsters by AnFaeB in the methanolic extract from NI-SFM at $50^{\circ} \mathrm{C}$. After only $10 \mathrm{~min}$, all the phenolic esters were hydrolyzed into free CA, which gave rise to a concentration of $68.1 \pm 1.7 \mu \mathrm{mol} / \mathrm{g}$ DDM with $95 \%$ hydrolysis yield (Table 4). 
chlorogenic acid was hydrolyzed more slowly (30 min instead of $10 \mathrm{~min}$ ) and was not highest concentration of CA was only $55.4 \pm 0.3 \mu \mathrm{mol} / \mathrm{g}$ DDM after $60 \mathrm{~min}$ incubation, which corresponded to a hydrolysis yield of only $77 \%$ (Table 4). It is worth noting that, in both cases (AnFaeB and ChlE), no decrease in the TCAD content was observed over enzymatic incubation time on methanolic extracts (Fig. 4), conversely to the crude NI meal (Fig. 3). This might indirectly confirm the presence of phenolic-degrading enzymes (i.e PPO for instance) in the meal that were removed after phenolic extraction with methanol.

On NI-SFM, the best CA yields were achieved through enzymatic hydrolysis of methanolic extract, particularly with AnFaeB that allowed fast, selective, and quantitative production of CA $(68.1 \pm 1.7 \mu \mathrm{mol} / \mathrm{DDM}$ from methanolic extract hydrolysis against $52.3 \pm 0.2 \mu \mathrm{mol} / \mathrm{g}$ DDM from crude NI-meal hydrolysis).

\subsection{Enzymatic hydrolysis of sinapic acid esters in NI-RSM and in the} corresponding methanolic extract with AnFaeA

Hydrolysis conditions ( $\mathrm{pH}$, temperature and enzyme concentration) for the enzymatic hydrolysis of sinapic esters present in an I-RSM (a commercial RSM thermally treated by cooking at $95-100^{\circ} \mathrm{C}$ followed by steam desolventizing at about $107^{\circ} \mathrm{C}$ ) was previously established by Odinot et al. (2017). These conditions were implemented on NI-RSM and on the corresponding methanolic extract. NI-RSM was chosen for its higher total sinapic acid derivatives (TSAD) content compared to the IRSM (Table 1). 
Manuscript

592

593

594

595

596

597

598

599

600

601

602

603

604

605

606

607

608

609

610

611

612

613

614

615

616

\subsubsection{AnFaeA hydrolysis of NI-RSM}

The evolution of the concentration of sinapine (SNP), sinapic acid (SA) and

TSAD during enzymatic hydrolysis of NI-RSM with AnFaeA (39 nkat/g meal, $55^{\circ} \mathrm{C}$,

$\mathrm{pH}$ 5.5) is charted in Fig. 5A. The maximum amount of SA released was $41.3 \pm 0.3$

$\mu \mathrm{mol} / \mathrm{g}$ DDM after 240 min of incubation with AnFaeA. Almost all the SNP initially

present in the meal $(31.7 \pm 0.6 \mu \mathrm{mol} \mathrm{SAE} / \mathrm{g} \mathrm{DDM})($ Fig. $5 \mathrm{~A})$ and the mono- and disinapoyl glucose isomers (Supplementary data Fig. S3A) were hydrolyzed at the end of incubation.

However, kaempferol-based sinapic acid derivatives, as well as di-sinapoyl gentiobiosides and some tri-sinapoyl gentiobiosides were not (or partially) hydrolyzed by the enzyme (supplementary data, Fig.S3A). These results were in agreement with our previous work on I-RSM (Odinot et al., 2017). TSAD content measured after the 30min pre-incubation step (Fig. 5A) was decreased by about $16 \%$ compared to the initial content in the unprocessed meal $(64.2 \pm 1.2 \mu \mathrm{mol} \mathrm{SAE} / \mathrm{g}$ DDM), possibly due to the activity of endogenous enzymes (possibly PPO) present in the crude meal. In the case of NI-RSM, no PPO-type activity was detectable in the meal in our assay conditions.

However, it is noteworthy that a laccase-encoding gene (AtTT10 gene) was identified in the genome of Brassica napus (Zhang et al., 2013). This PPO was involved in proanthocyanidin polymerization and lignin biosynthesis as well as seed coat pigmentation. Conversely, this decrease was not observed in enzymatic hydrolysis applied to an I-RSM (Odinot et al., 2017). Like for I-SFM, but in contrast to NI-RSM, the thermal treatments $\left(95-107^{\circ} \mathrm{C}\right)$ applied to I-RSM seemed to inactivate endogenous phenolic-degrading enzymes.

Figure 5 (suggested location) 
Manuscript

\subsubsection{AnFaeA hydrolysis of the NI-RSM methanolic extract}

Like for NI-SFM, enzymatic hydrolysis was also performed on phenolic extracts from NI-RSM obtained after a sequence of methanolic extraction, drying, then solubilization in reaction buffer. The time- concentrations of SNP, SA and TSAD during enzymatic hydrolysis of NI-RSM dry methanolic extract with AnFaeA (39 nkat/g meal, $55^{\circ} \mathrm{C}, \mathrm{pH} 5.5$ ) is shown in Fig. 5B. Unexpectedly, the maximum amount of SA released $(32.3 \pm 0.4 \mu \mathrm{mol} / \mathrm{g} \mathrm{DDM})$ was lower than the amount obtained from NI$\operatorname{RSM}(41.3 \pm 0.3 \mu \mathrm{mol} / \mathrm{g}$ DDM) (Table 5), concomitantly with the appearance of a new phenolic compound in the reaction medium (Fig. 5B, green bar) that corresponded to a peak with a retention time of $22.25 \mathrm{~min}$ in our HPLC conditions (Supplementary data Fig. S3B).

Table 5 (suggested location)

$$
\text { Based on its retention time in the HPLC chromatogram (Compound } \underline{\mathbf{9}} \text {, }
$$

Supplementary data Fig. S3B), its maximum wavelength absorption of $326 \mathrm{~nm}$, and its mass and NMR $\left({ }^{1} \mathrm{H},{ }^{13} \mathrm{C}\right)$ spectra (Supplementary data Fig. S4 and Fig. S5), the new compound was 1,2-di- $O$-sinapoyl- $\beta$-D-glucose. Therefore, given the presence of significant amounts of glucose (Naczk \&Shahidi, 1990), as well as mono- and disinapoyl glucose isomers in the NI-RSM extract (Laguna et al., 2018), it can be reasonably assumed that this new compound resulted from transesterification of sinapine with the aforementioned molecules extracted from the meal. If so, these results would confirm the well-known acyl transferase activity of AnFaeA (Hatzakis and Smonou, 2005; Hüttner et al., 2017; Vafiadi et al., 2009). However, the reason why such a reaction only occurred in the NI-RSM methanolic extract remains to elucidate. TSAD content measured during enzymatic hydrolysis of the methanolic extract $(59.2 \pm$ $2.3 \mu$ mol SAE/DDM) remained higher than TSAD content measured during meal 


\section{Manuscript}

hydrolysis $(53.1 \pm 1.0 \mu \mathrm{mol}$ SAE/ DDM). This might corroborate the presence of phenolic-degrading endogenous enzymes in the crude meal.

Hydrolysis of the NI-RSM methanolic extract was also performed at $37^{\circ} \mathrm{C}$ in order to assess the possible influence of temperature on yield of 1,2-di- $O$-sinapoyl- $\beta$-Dglucose synthesis (Fig. $5 \mathrm{C}$ ). At $37^{\circ} \mathrm{C}$, TSAD concentration (65.6 $\pm 2.3 \mu \mathrm{mol} / \mathrm{DDM}$ ) measured during hydrolysis remained stable throughout the incubation time at an equivalent level to the initial content in the unprocessed meal $(64.2 \pm 1.2 \mu \mathrm{mol} \mathrm{SAE} / \mathrm{g}$ DDM). The decrease over time of SNP was slightly slower at $37^{\circ} \mathrm{C}$ than at $55^{\circ} \mathrm{C}$ (Fig. 5C): hydrolysis was complete in less than $120 \mathrm{~min}$ at $55^{\circ} \mathrm{C}$ whereas $3 \%$ of SNP remained in the medium even after $240 \mathrm{~min}$ at $37^{\circ} \mathrm{C}$. Production of 1,2-di-O-sinapoyl- $\beta$ D-glucose was higher overall (e.g. $8.0 \pm 0.8 \mu \mathrm{mol} \mathrm{SAE} / \mathrm{g}$ DDM at $37^{\circ} \mathrm{C}$ against $5.7 \pm$ $0.3 \mu \mathrm{mol} \mathrm{SAE} / \mathrm{g}$ DDM at $55^{\circ} \mathrm{C}$ after 240 min incubation), which may suggest that lower temperature facilitated acyl transfer more than sinapine hydrolysis, which occurs in both conditions.

Taken together, the results presented in section 3.4 converged to show the best yield of SA came from hydrolysis performed directly in the crude NI-RSM with AnFaeA compared to hydrolysis of the corresponding methanolic extract. The enzymatic treatment of the NI-RSM methanolic extract seemed to be characterized by acyl transfer reactions that reduce the overall yield of free SA release.

\section{Conclusion}

It is possible to obtain free CA from sunflower meal and free SA from rapeseed meal by alkaline hydrolysis and solvent extraction (Vuorela et al., 2003, Zago et al., 2015b), but in high temperature, strong base and toxic solvent conditions, which runs counter to a 'green' process. Here we showed that A. niger AnFaeB, ChlE and AnFaeA were very efficient catalysts for the enzymatic release of CA and SA from both industrial and non-industrial meals. To the best of our knowledge, this is the first time 


\section{Manuscript}

that $\mathrm{AnFaeB}$ and $\mathrm{ChlE}$ were applied on sunflower meals as raw natural substrates.

AnFaeB was able to hydrolyze all the mono- and di-caffeoylquinic acid isomers, together with the coumaroylquinic and feruloylquinic acid isomers identified in SFMs, whereas ChlE was unable to hydrolyze 3-CQA. The non-industrial meals processed under mild thermal conditions presented the advantage of higher initial phenolics contents. However, phenolic acid release was hampered by phenolic oxidation sidereactions, seemingly due to meal endogenous PPO-type activities, which is a major drawback for industrial applications. Here we found evidence that using an intermediary step of phenolic extraction with methanol, before enzymatic hydrolysis, could overcome this drawback for NI-SFM but not NI-RSM due to AnFaeA transesterification sidereactions. Nevertheless, this acyl transfer activity of AnFaeA could prove beneficial for the enzymatic synthesis of novel sinapic and ferulic acid esters with sugars or polyols. Of all the substrates tested for enzymatic hydrolysis, industrial rapeseed meal and nonindustrial sunflower meal extract showed the best compromise between the three following parameters: initial TPC, hydrolysis yields, and amounts of CA and SA released. The proof of concept of such an enzymatic hydrolysis process was already successfully scaled-up in a 10-L bioreactor in the case of FaeA and raw industrial RSM (Odinot et al., 2017). In addition, regarding enzymatic hydrolysis applied to meal methanolic extract, the extraction of phenolics by ethanol (less toxic and biosourced solvent, almost as efficient as methanol) followed by concentration/desolventization steps could be easily implemented at industrial scale as it is already done with hexane for instance. In the case of sunflower meal extract, this process may be advantageous since phenolic concentration as well as enzyme load would be better controlled, limiting matrix effect in the same time. This work opens new perspectives on the biotechnological applications of fungal Faes and ChlEs to other hydroxycinnamic acidcontaining raw materials, including green coffee bean wastes, co-products of rapeseed 
Manuscript

695

696

697

698

699

700

701

702

703

704

705

706

707

708

709

710

711

712

713

714

715

716

717

718

719

and sunflower crops (e.g. stems, straws, seed shells, sunflower capitula) as well as other oilseed plants (mustard, flax).

\section{Acknowledgements}

This work was funded by the Technical Centre for Oilseed Crops, Grain Legumes and Industrial Hemp (TERRES INOVIA, Pessac, France) and the Inter-Branch Organization for Vegetable Oils and Proteins (TERRES UNIVIA, Paris, France). This work was also funded and performed, in partnership with the SAS PIVERT, within the frame of the French Institute for the Energy Transition (Institut pour la Transition Energétique (ITE) P.I.V.E.R.T. (www.institut-pivert.com) selected as an Investment for the Future ("Investissements d'Avenir"). The French Government under the reference ANR-00101 supported this work, as part of the Investments for the Future.

\section{Author Contributions}

Jérôme Lecomte, Oscar Laguna and Anne Lomascolo conceived, designed, supervised the experiments, and wrote the paper. Oscar Laguna, Elise Odinot, Alexandra Bisotto and Bruno Baréa performed the experiments. Frédéric Fine, Jean-Claude Sigoillot and Pierre Villeneuve contributed to the conception of the work and help to write the final draft of the paper. Craig B. Faulds and Laurence Lesage-Meessen brought expertise on feruloyl esterases. Eric Record is at the origin of Aspergillus niger recombinant strains. All the authors contributed to finalize the manuscript.

Competing interests: The authors have declared no conflict of interest.

\section{References}

Aider, M., Barbana, C., 2011. Canola proteins: composition, extraction, functional properties, bioactivity, applications as a food ingredient and allergenicity - A 
Manuscript

practical and critical review. Trends Food Sci. Technol. 22, 21-39. https://doi.org/10.1016/j.tifs.2010.11.002

Aouf, C., Lecomte, J., Villeneuve, P., Dubreucq, E., Fulcrand, H., 2012. Chemoenzymatic functionalization of gallic and vanillic acids: synthesis of bio-based epoxy resins prepolymers. Green Chem. 14, 2328-2336. https://doi.org/10.1039/c2gc35558b

Asther, Mi., Estrada Alvarado, M.I., Haon, M., Navarro, D., Asther, Ma., LesageMeessen, L., Record, E., 2005. Purification and characterization of a chlorogenic acid hydrolase from Aspergillus niger catalysing the hydrolysis of chlorogenic acid. J. Biotechnol. 115, 47-56. https://doi.org/10.1016/j.jbiotec.2004.07.009

Baumert, A., Milkowski, C., Schmidt, J., Nimtz, M., Wray, V., Strack, D., 2005. Formation of a complex pattern of sinapate esters in Brassica napus seeds, catalyzed by enzymes of a serine carboxypeptidase-like acyltransferase family? Phytochem 66, 1334-1345. https://doi.org/10.1016/j.phytochem.2005.02.031

Benoit, I., Asther, Mi., Bourne, Y., Navarro, D., Canaan, S., Lesage-Meessen, L., Herweijer, M., Coutinho, P.M., Asther, Ma., Record, E., 2007. Gene overexpression and biochemical characterization of the biotechnologically relevant chlorogenic acid hydrolase from Aspergillus niger. Appl. Environ. Microbiol. 73, 5624-5632. https://doi.org/10.1128/AEM.00374-07

Benoit, I., Navarro, D., Marnet, N., Rakotomanomana, N., Lesage-Meessen, L., Sigoillot, J.-C., Asther, Ma., Asther, Mi., 2006. Feruloyl esterases as a tool for the release of phenolic compounds from agro-industrial by-products. Carbohydr. Res. 341, 1820-1827. https://doi.org/10.1016/j.carres.2006.04.020

Borredon, M.-E., Berger, M., Dauguet, S., Labalette, F., Merrien, A., Mouloungui, Z., Raoul, Y., 2011. Débouchés actuels et futures du tournesol produit en FranceCritères de qualité. Innov. Agron. 14, 19-38. 
Manuscript

Brézillon, C., Kroon, P.A., Faulds, C.B., Brett, G.M., Williamson, G., 1996. Novel ferulic acid esterases are induced by growth of Aspergillus niger on sugar-beet pulp. Appl. Microbiol. Biotechnol. 45, 371-376. https://doi.org/10.1007/s002530050698

Cai, R., Arntfield, S.D., 2001. A rapid high-performance liquid chromatographic method for the determination of sinapine and sinapic acid in canola seed and meal. J. Am. Oil Chem. Soc. 78, 903-910. https://doi.org/10.1007/s11746-001$0362-4$

Campbell, L., Rempel, C., Wanasundara, J., 2016. Canola/rapeseed protein: future opportunities and directions-workshop proceedings of IRC 2015. Plants 5, 17. https://doi.org/10.3390/plants5020017

Diot-Néant, F., Migeot, L., Hollande, L., Reano, F.A., Domenek, S., Allais, F., 2017. Biocatalytic synthesis and polymerization via ROMP of new biobased phenolic monomers: a greener process toward sustainable antioxidant polymers. Front. Chem. 5:126. https://doi.org/10.3389/fchem.2017.00126

Faulds, C.B., 2010. What can feruloyl esterases do for us? Phytochem. Rev. 9, 121-132. https://doi.org/10.1007/s11101-009-9156-2

Faulds, C.B., Williamson, G., 1994. Purification and characterization of a ferulic acid esterase (FAE-III) from Aspergillus niger: specificity for the phenolic moiety and binding to microcrystalline cellulose Microbiol. 140, 779-787. https://doi.org/10.1099/00221287-140-4-779

Fetzer, A., Herfellner, T., Eisner, P., 2019. Rapeseed protein concentrates for non-food applications prepared from pre-pressed and cold-pressed press cake via acidic precipitation and ultrafiltration. Ind. Crops Prod. 132, 396-406. https://doi.org/10.1016/j.indcrop.2019.02.039 
Manuscript

Fetzer, A., Herfellner, T., Stäbler, A., Menner, M., Eisner, P., 2018. Influence of process conditions during aqueous protein extraction upon yield from pre-pressed and cold-pressed rapeseed press cake. Ind. Crops Prod. 112, 236-246. https://doi.org/10.1016/j.indcrop.2017.12.011

Fine, F., Lucas, J.-L., Chardigny, J.-M., Redlingshöfer, B., Renard, M., 2015. Food losses and waste in the French oilcrops sector. OCL 22, A302. https://doi.org/10.1051/ocl/2015012

González-Pérez, S., Vereijken, J.M., 2007. Sunflower proteins: overview of their physicochemical, structural and functional properties. J. Sci. Food Agric. 87, 2173-2191. https://doi.org/10.1002/jsfa.2971

Gopalan, N., Rodríguez-Duran, L.V., Saucedo-Castaneda, G., Nampoothiri, K.M., 2015. Review on technological and scientific aspects of feruloyl esterases: A versatile enzyme for biorefining of biomass. Bioresour. Technol. 193, 534-544. https://doi.org/10.1016/j.biortech.2015.06.117

Gullón, B., Eibes, G., Moreira, M.T., Herrera, R., Labidi, J., Gullón, P., 2018. Yerba mate waste: a sustainable resource of antioxidant compounds. Ind. Crops Prod. 113, 398-405. https://doi.org/10.1016/j.indcrop.2018.01.064

Guo, S., Ge, Y., Na Jom, K., 2017. A review of phytochemistry, metabolite changes, and medicinal uses of the common sunflower seed and sprouts (Helianthus annuus L.). Chem. Cent. J. 11:95. https://doi.org/10.1186/s13065-017-0328-7

Halaouli, S., Asther, Mi., Kruus, K., Guo, L., Hamdi, M., Sigoillot, J.-C., Asther, Ma., Lomascolo, A., 2005. Characterization of a new tyrosinase from Pycnoporus species with high potential for food technological applications. J Appl Microbiol. 98, 332-343. https://doi:10.1111/j.1365-2672.2004.02481.x 
Manuscript

Hatzakis, N.S., Smonou, I., 2005. Asymmetric transesterification of secondary alcohols catalyzed by feruloyl esterase from Humicola insolens. Bioorganic Chem. 33, 325-337. https://doi.org/10.1016/j.bioorg.2005.05.002

Hüttner, S., Zezzi Do Valle Gomes, M., Iancu, L., Palmqvist, A., Olsson, L., 2017. Immobilisation on mesoporous silica and solvent rinsing improve the transesterification abilities of feruloyl esterases from Myceliophthora thermophila. Bioresour. Technol. 239, 57-65. https://doi.org/10.1016/j.biortech.2017.04.106

Ivanova, P., Chalova, V., Uzunova, G., Koleva, L., Manolov, I., 2016. Biochemical characterization of industrially produced rapeseed meal as a protein source in food industry. Agric. Agric. Sci. Procedia 10, 55-62. https://doi.org/10.1016/j.aaspro.2016.09.009

Karamać, M., Kosińska, A., Estrella, I., Hernández, T., Dueñas, M., 2012. Antioxidant activity of phenolic compounds identified in sunflower seeds. Eur. Food Res. Technol. 235, 221-230. https://doi.org/10.1007/s00217-012-1751-6

Khattab, R., Eskin, M., Aliani, M., Thiyam, U., 2010. Determination of sinapic acid derivatives in canola extracts using high-performance liquid chromatography. J. Am. Oil Chem. Soc. 87, 147-155. https://doi.org/10.1007/s11746-009-1486-0

Kreps, F., Vrbiková, L., Schmidt, Š., 2014. Industrial rapeseed and sunflower meal as source of antioxidants. Int. Journal of Engineering Research and Applications 4, $45-54$.

Laguerre, M., Bayrasy, C., Lecomte, J., Chabi, B., Decker, E.A., Wrutniak-Cabello, C., Cabello, G., Villeneuve, P., 2013. How to boost antioxidants by lipophilization? Biochimie 95, 20-26. https://doi.org/10.1016/j.biochi.2012.07.018

Laguerre, M., López Giraldo, L.J., Lecomte, J., Figueroa-Espinoza, M.-C., Baréa, B., Weiss, J., Decker, E.A., Villeneuve, P., 2010. Relationship between 

hydrophobicity and antioxidant ability of "phenolipids" in emulsion: a parabolic effect of the chain length of rosmarinate esters. J. Agric. Food Chem. 58, 28692876. https://doi.org/10.1021/jf904119v

Laguerre, M., Wrutniak-Cabello, C., Chabi, B., López Giraldo, L.J., Lecomte, J., Villeneuve, P., Cabello, G., 2011. Does hydrophobicity always enhance antioxidant drugs? A cut-off effect of the chain length of functionalized chlorogenate esters on ROS-overexpressing fibroblasts: cut-off effect of phenolipid antioxidants. J. Pharm. Pharmacol. 63, 531-540. https://doi.org/10.1111/j.2042-7158.2010.01216.x

Laguna, O., Barakat, A., Alhamada, H., Durand, E., Baréa, B., Fine, F., Villeneuve, P., Citeau, M., Dauguet, S., Lecomte, J., 2018. Production of proteins and phenolic compounds enriched fractions from rapeseed and sunflower meals by dry fractionation processes. Ind. Crops Prod. 118, 160-172. https://doi.org/10.1016/j.indcrop.2018.03.045

Lecomte, J., Giraldo, L.J.L., Laguerre, M., Baréa, B., Villeneuve, P., 2010. Synthesis, characterization and free radical scavenging properties of rosmarinic acid fatty esters. J. Am. Oil Chem. Soc. 87, 615-620. https://doi.org/10.1007/s11746-010$1543-8$

Levasseur, A., Benoit, I., Asther, Mi., Asther, Ma., Record, E., 2004. Homologous expression of the feruloyl esterase B gene from Aspergillus niger and characterization of the recombinant enzyme. Protein Expr. Purif. 37, 126-133. https://doi.org/10.1016/j.pep.2004.05.019

Licata, M., La Bella, S., Lazzeri, L., Matteo, R., Leto, C., Massaro, F., Tuttolomondo, T., 2018. Agricultural feedstocks of two Brassica oilseed crops and energy cogeneration with pure vegetable oil for a sustainable short agro-energy chain in 
Manuscript

Sicily (Italy). Ind. Crops Prod. 117, 140-148. https://doi.org/10.1016/j.indcrop.2018.02.032

Lomascolo, A., Uzan-Boukhris, E., Sigoillot, J.-C., Fine, F., 2012. Rapeseed and sunflower meal: a review on biotechnology status and challenges. Appl. Microbiol. Biotechnol. 95, 1105-1114. https://doi.org/10.1007/s00253-012-42506

Mailer, R.J., 2008. Anti-nutritional components, fibre, sinapine and glucosinolate content, in Australian canola (Brassica napus L.) meal. J. Am. Oil Chem. Soc. v. 85, 937-944. https://doi.org/10.1007/s11746-008-1268-0

McClements, D.J., Decker, E., 2018. Interfacial antioxidants: a review of natural and synthetic emulsifiers and coemulsifiers that can inhibit lipid oxidation. J. Agric. Food Chem. 66, 20-35. https://doi.org/10.1021/acs.jafc.7b05066

Milkowski, C., Strack, D., 2010. Sinapate esters in brassicaceous plants: biochemistry, molecular biology, evolution and metabolic engineering. Planta 232, 19-35. https://doi.org/10.1007/s00425-010-1168-z

Naczk, M., Shahidi, F., 1990. Carbohydrates of canola and rapeseed. In: Shahidi F. (eds) canola and rapeseed. Springer, Boston, MA. https://doi.org/10.1007/978-14615-3912-4_12

Odinot, E., Fine, F., Sigoillot, J.-C., Navarro, D., Laguna, O., Bisotto, A., Peyronnet, C., Ginies, C., Lecomte, J., Faulds, C., Lomascolo, A., 2017. A two-step bioconversion process for canolol production from rapeseed meal combining an Aspergillus niger feruloyl esterase and the fungus Neolentinus lepideus. Microorganisms 5, 67. https://doi.org/10.3390/microorganisms5040067

Ouerghemmi, I., Bettaieb Rebey, I., Rahali, F.Z., Bourgou, S., Pistelli, L., Ksouri, R., Marzouk, B., Saidani Tounsi, M., 2017. Antioxidant and antimicrobial phenolic compounds from extracts of cultivated and wild-grown Tunisian Ruta 
Manuscript

chalepensis. J. Food Drug Anal. 25, 350-359. https://doi.org/10.1016/j.jfda.2016.04.001

Oueslati, S., Ksouri, R., Falleh, H., Pichette, A., Abdelly, C., Legault, J., 2012. Phenolic content, antioxidant, anti-inflammatory and anticancer activities of the edible halophyte Suaeda fruticosa Forssk. Food Chem. 132, 943-947. https://doi.org/10.1016/j.foodchem.2011.11.072

Pion, F., Ducrot, P.-H., Allais, F., 2014. Renewable alternating aliphatic-aromatic copolyesters derived from biobased ferulic acid, diols, and diacids: sustainable polymers with tunable thermal properties. Macromol. Chem. Phys. 215, 431-439. https://doi.org/10.1002/macp.201300702

Ramos-de-la-Peña, A.M., Contreras-Esquivel, J.C., 2016. Methods and substrates for feruloyl esterase activity detection, a review. J. Mol. Catal. B Enzym. 130, 74-87. https://doi.org/10.1016/j.molcatb.2016.05.004

Reano, A.F., Chérubin, J., Peru, A.M.M., Wang, Q., Clément, T., Domenek, S., Allais, F., 2015. Structure-activity relationships and structural dsign optimization of a series of $p$-hydroxycinnamic acids-based bis- and trisphenols as novel sustainable antiradical/antioxidant additives. ACS Sustain. Chem. Eng. 3, 3486-3496. https://doi.org/10.1021/acssuschemeng.5b01281

Record, E., Asther, Mi., Sigoillot, C., Pagès, S., Punt, P.J., Delattre, M., Haon, M., van den Hondel, C.A.M.J.J., Sigoillot, J.-C., Lesage-Meessen, L., Asther, Ma., 2003. Overproduction of the Aspergillus niger feruloyl esterase for pulp bleaching application. Appl. Microbiol. Biotechnol. 62, 349-355. https://doi.org/10.1007/s00253-003-1325-4

Shahidi, F., Ambigaipalan, P., 2015. Phenolics and polyphenolics in foods, beverages and spices: antioxidant activity and health effects - A review. J. Funct. Foods 18, 820-897. https://doi.org/10.1016/j.jff.2015.06.018 
Manuscript

Shahidi, F., Yeo, J., 2016. Insoluble-bound phenolics in food. Molecules 21, 1216. https://doi.org/10.3390/molecules21091216

Siger, A., Czubinski, J., Dwiecki, K., Kachlicki, P., Nogala-Kalucka, M., 2013. Identification and antioxidant activity of sinapic acid derivatives in Brassica napus L. seed meal extracts: main phenolic compounds in rapeseed. Eur. J. Lipid Sci. Technol. 115, 1130-1138. https://doi.org/10.1002/ejlt.201300077

Sørensen, A.-D.M., Lyneborg, K.S., Villeneuve, P., Jacobsen, C., 2015. Alkyl chain length impacts the antioxidative effect of lipophilized ferulic acid in fish oil enriched milk. J. Funct. Foods 18, 959-967. https://doi.org/10.1016/j.jff.2014.04.008

Sripad, G., and Narasinga Rao M.S., 1987. Effect of methods to remove polyphenols from sunflower meal on the physicochemical properties of the proteins. J. Agric. Food Chem., 1987, 35, 962-967. https://doi.org/10.1021/jf00078a025

Suriyarak, S., Bayrasy, C., Schmidt, H., Villeneuve, P., Weiss, J., 2013. Impact of fatty acid chain length of rosmarinate esters on their antimicrobial activity against Staphylococcus carnosus LTH1502 and Escherichia coli K-12 LTH4263. J. Food Protection 76, 1539-1548. https://doi.org/10.4315/0362-028X.JFP-12-254

Szydłowska-Czerniak, A., Rabiej, D., Krzemiński, M., 2018. Synthesis of novel octyl sinapate to enhance antioxidant capacity of rapeseed-linseed oil mixture: octyl sinapate as a new lipophilic antioxidant. J. Sci. Food Agric. 98, 1625-1631. https://doi.org/10.1002/jsfa.8637

Szydłowska-Czerniak, A., Trokowski, K., Szłyk, E., 2011. Optimization of extraction conditions of antioxidants from sunflower shells (Helianthus annuus L.) before and after enzymatic treatment. Ind. Crops Prod. 33, 123-131. https://doi.org/10.1016/j.indcrop.2010.09.016 
Manuscript

Tong, J., Ma, B., Ge, L., Mo, Q., Zhou, G., He, J., Wang, Y., 2015. Dicaffeoylquinic acid-enriched fraction of Cichorium glandulosum seeds attenuates experimental type 1 diabetes via multipathway protection. J. Agric. Food Chem. 63, 1079110802. https://doi.org/10.1021/acs.jafc.5b04552

Ugolini, L., Cinti, S., Righetti, L., Stefan, A., Matteo, R., D’Avino, L., Lazzeri, L., 2015. Production of an enzymatic protein hydrolyzate from defatted sunflower seed meal for potential application as a plant biostimulant. Ind. Crops Prod. 75, 15-23. https://doi.org/10.1016/j.indcrop.2014.11.026

Vafiadi, C., Topakas, E., Nahmias, V.R., Faulds, C.B., Christakopoulos, P., 2009. Feruloyl esterase-catalysed synthesis of glycerol sinapate using ionic liquids mixtures. J. Biotechnol. 139, 124-129. https://doi.org/10.1016/j.jbiotec.2008.08.008

Vuorela, S., Meyer, A.S., Heinonen, M., 2003. Quantitative analysis of the main phenolics in rapeseed meal and oils processed differently using enzymatic hydrolysis and HPLC. Eur. Food Res. Technol. 217, 517-523. https://doi.org/10.1007/s00217-003-0811-3

Wang, S., Tateyama, S., Kaneko, D., Ohki, S., Kaneko, T., 2011. Synthesis of welldefined hyperbranched polymers bio-based on multifunctional phenolic acids and their structure-thermal property relationships. Polym. Degrad. Stab. 96, 20482054. https://doi.org/10.1016/j.polymdegradstab.2011.10.003

Weisz, G.M., Kammerer, D.R., Carle, R., 2009. Identification and quantification of phenolic compounds from sunflower (Helianthus annuus L.) kernels and shells by HPLC-DAD/ESI-MSn. Food Chem. 115, 758-765. https://doi.org/10.1016/j.foodchem.2008.12.074

Wildermuth, S.R., Young, E.E., Were, L.M., 2016. Chlorogenic acid oxidation and its reaction with sunflower proteins to form green-colored complexes: chlorogenic 
Manuscript

acid oxidation. Compr. Rev. Food Sci. Food Saf. 15, 829-843. https://doi.org/10.1111/1541-4337.12213

Zago, E., Durand, E., Barouh, N., Lecomte, J., Villeneuve, P., Aouf, C., 2015 a. Synthesis of lipophilic antioxidants by a lipase-B-catalyzed addition of peracids to the double bond of 4-vinyl-2-methoxyphenol. J. Agric. Food Chem. 63, 90699075. https://doi.org/10.1021/acs.jafc.5b03551

Zago, E., Lecomte, J., Barouh, N., Aouf, C., Carré, P., Fine, F., Villeneuve, P., $2015 b$. Influence of rapeseed meal treatments on its total phenolic content and composition in sinapine, sinapic acid and canolol. Ind. Crops Prod. 76, 10611070. https://doi.org/10.1016/j.indcrop.2015.08.022

Zhang, K., Lu, K., Qu, C., Liang, Y., Wang, R., Chai, Y., Li, J. 2013. Gene silencing of BnTT10 family genes causes retarded pigmentation and lignin reduction in the seed coat of Brassica napus. Plos One. 8, e61247. https://doi.org/10.1371/journal.pone.0061247

\section{Figures captions}

Fig. 1. HPLC chromatogram of industrial SFM methanolic extract at $326 \mathrm{~nm}$. Main identified phenolics: 3-O-caffeoylquinic acid (3-CQA) (1), 4- $O$-caffeoylquinic acid (4-CQA) (2), 5-Ocaffeoylquinic acid (5-CQA) (3), caffeic acid (CA) (4), 5-O-coumaroylquinic acid (5-CoQA) (5), 5-O-feruloylquinic acid (5-FQA), (6), 3,5-di- $O$-caffeoylquinic acid (3,5-diCQA) (7) and 4,5-di-O-caffeoylquinic acid (4,5-diCQA) (8). 


\section{Manuscript}

Fig. 2. Hydrolysis kinetics of the main CAEsters in industrial SFM, as a function of enzyme type: AnFaeB (A); ChlE (B), and enzyme concentration. CAEsters: 4- and 5-O-caffeoylquinic acid (4- and 5-CQA, 1); 3-O-caffeoylquinic acid (3-CQA, 2); 3,5-di- $O$-caffeoylquinic acid (3,5diCQA, 3), 4,5-di-O-caffeoylquinic acid (4,5-diCQA, 4) and caffeic acid (CA, 5). Hydrolysis conditions: $\mathrm{pH} 6,50^{\circ} \mathrm{C}$. Before starting the enzymatic hydrolysis, the reaction mixture was preincubated for $30 \mathrm{~min}$ for homogenization. Values are mean $\pm \mathrm{SD}(\mathrm{n}=2)$ and expressed as caffeic acid equivalents (CAE). For each series, values followed by same superscript letters are not significantly different, $\mathrm{p} \leq 0.05$.

Fig. 3. Time course of 4- and 5-O-caffeoylquinic acid (4- and 5-CQA), caffeic acid (CA) and total caffeic acid derivatives (TCAD) concentrations during enzymatic hydrolysis with AnFaeB (pH6, 30 nkat/g meal) (A) and ChlE (pH6, $10 \mathrm{nkat} / \mathrm{g}$ meal) (B), applied to non-industrial SFM at $50^{\circ} \mathrm{C}$. Before starting the enzymatic hydrolysis, the reaction mixture was pre-incubated for 30 min for homogenization. Initial PC: Initial phenolic concentration in non-industrial SFM. Values are mean $\pm \mathrm{SD}(\mathrm{n}=2)$ and expressed as caffeic acid equivalents (CAE). Values followed by same superscript letters are not significantly different, $\mathrm{p} \leq 0.05$

Fig. 4. Time course of 4- and 5-O-caffeoylquinic acid (4- and 5-CQA), caffeic acid (CA) and total caffeic acid derivatives (TCAD) concentrations during enzymatic hydrolysis with AnFaeB (pH6, 30 nkat/g meal) (A) and ChlE (pH6, 10 nkat/g meal) (B), applied to non-industrial SFM methanolic extract at $50^{\circ} \mathrm{C}$. Before starting the enzymatic hydrolysis, the reaction mixture was pre-incubated for $30 \mathrm{~min}$ for homogenization. Initial PC: Initial phenolic concentration in nonindustrial SFM methanolic extracts. Values are mean \pm SD $(n=2)$ and expressed as caffeic acid equivalents (CAE). Values followed by same superscript letters are not significantly different, $p$ $\leq 0.05$.

Fig. 5. Time course of sinapine (SNP), sinapic acid (SA), 1,2-di- $O$-sinapoyl- $\beta$-D-glucose $(1,2$ diSG) and total sinapic acid derivatives (TSAD) concentrations during enzymatic hydrolysis with AnFaeA (pH5.5, $39 \mathrm{nkat} / \mathrm{g}$ meal) applied to non-industrial RSM at $55^{\circ} \mathrm{C}(\mathbf{A})$, and to non- 


\section{Manuscript}

industrial RSM methanolic extract at either $55^{\circ} \mathrm{C}(\mathbf{B})$ or $37^{\circ} \mathrm{C}(\mathbf{C})$. Before starting the enzymatic hydrolysis, the reaction mixture was pre-incubated for $30 \mathrm{~min}$ for homogenization. Initial PC: Initial phenolic concentration in non-industrial RSM (A) or in non-industrial RSM methanolic extract $(B, C)$. Values are mean $\pm S D(n=2)$ and expressed as sinapic acid equivalents (SAE). Values followed by same superscript letters are not significantly different, $\mathrm{p} \leq 0.05$.

Supplementary data. Fig. S1. Chromatograms obtained after the enzymatic hydrolysis of the industrial SFM with 20 nkat AnFaeB/g meal (A) and 30 nkat ChlE/g meal (B) at t $=0$ min (red) and $\mathrm{t}=240 \mathrm{~min}$ (black) at $326 \mathrm{~nm}$. 3-O-caffeoylquinic acid (3-CQA) (1), 4-O-caffeoylquinic acid (4-CQA) (2), 5-O-caffeoylquinic acid (5-CQA) (3), caffeic acid (CA) (4), 5-Ocoumaroylquinic acid (5-CQA) (5), 5- $O$-feruloylquinic acid (5-FQA)(6), 3,5-di- $O$ caffeoylquinic acid (3,5-diCQA) (7) and 4,5-di-O-caffeoylquinic acid (4,5-diCQA) (8).

Supplementary data Fig. S2. Time course of 3- $O$-caffeoylquinic acid (3-CQA), 3,5-di- $O$ caffeoylquinic acid (3,5-diCQA) and 4,5-di- $O$-caffeoylquinic acid (4,5-diCQA) during enzymatic treatment with $\mathbf{C h l E}$ (pH6, 10 nkat/g meal) applied to non-industrial SFM at $50^{\circ} \mathrm{C}$ (A), and to non-industrial SFM methanolic extract at $50^{\circ} \mathrm{C}(\mathbf{B})$. Before starting the enzymatic hydrolysis, the reaction mixture was pre-incubated for $30 \mathrm{~min}$ for homogenization. Initial PC: Initial phenolic concentration in non-industrial SFM. Values are mean \pm SD $(n=2)$ and expressed in caffeic acid equivalents (CAE). Values followed by same superscript letters are not significantly different, $\mathrm{p} \leq 0.05$.

Supplementary data Fig. S3. HPLC chromatograms obtained from the enzymatic hydrolysis of the non-industrial RSM (A) and the corresponding methanolic extract (B) with 39 nkat AnFaeA $/ g$ meal at $t=0$ (red) and $t=240$ min (black) at $323 \mathrm{~nm}$. Sinapoyl glucose isomer (1), Sinapine (SNP) (2), Kaempferol-based sinapic esters (3), trans-SA (4), cis-SA (5), di-sinapoylgentiobioside isomers (6), di-sinapoyl glucose isomer (7), tri-sinapoyl gentiobioside isomers (8) and 1,2-di- $O$-sinapoyl- $\beta$-D-glucose (9). 
Manuscript

1033 Supplementary data Fig. S4. Chemical structure, ${ }^{13} \mathrm{C}-\mathrm{NMR}\left(125 \mathrm{MHz}\right.$, DMSO-d 6 ) and ${ }^{1} \mathrm{H}-$

1034 NMR (500 MHz, DMSO-d $)$ data for 1,2-di- $O$-sinapoyl- $\beta$-D-glucose

1035

1036 Supplementary data Fig. S5. Mass spectrum (negative mode) and fragmentation scheme for

1037 1,2-di- $O$-sinapoyl- $\beta$-D-glucose

1038

1039

1040

1041

1042

1043

1044

1045

1046

1047

1048 
Table 1. Lipid and moisture content of SFM and RSM samples ${ }^{\#}$.

\begin{tabular}{lll}
\hline & Lipid content $(\% \mathrm{DM})$ & Moisture $(\% \mathrm{DM})$ \\
\hline NI-SFM & $1.5 \pm 0.0$ & $7.3 \pm 0.8$ \\
I-SFM & $1.9 \pm 0.3$ & $10.5 \pm 0.7$ \\
NI-RSM & $1.4 \pm 0.0$ & $13.1 \pm 0.3$ \\
I-RSM & $1.5 \pm 0.06$ & $10 \pm 0.1$ \\
\hline
\end{tabular}

\#Values are mean \pm SD $(n=3)$. 
Table 2. Phenolic content of Non-Industrial and Industrial SFM ${ }^{\#}$

\begin{tabular}{lcccc}
\hline & $\begin{array}{l}\text { NI-SFM } \\
\text { Before alkaline } \\
\text { hydrolysis }\end{array}$ & $\begin{array}{l}\text { After alkaline } \\
\text { hydrolysis }\end{array}$ & $\begin{array}{l}\text { I-SFM } \\
\text { Before alkaline } \\
\text { hydrolysis }\end{array}$ & $\begin{array}{l}\text { After alkaline } \\
\text { hydrolysis }\end{array}$ \\
\hline $\begin{array}{l}\text { Chlorogenic acid } \\
(\mu \mathrm{mol} \mathrm{CAE} / \mathrm{g} \text { DDM })\end{array}$ & $55.8 \pm 0.9^{\mathrm{b}}$ & n.d. & $41.4 \pm 2.5^{\mathrm{c}}$ & n.d. \\
$\begin{array}{l}\text { Caffeic acid } \\
(\mu \mathrm{mol} / \mathrm{g} \text { DDM })\end{array}$ & $1.2 \pm 0.0^{\mathrm{e}}$ & n.d. & $2.1 \pm 0.5^{\mathrm{d}}$ & n.d. \\
$\begin{array}{l}\text { TCAD* } \\
(\mu \mathrm{mol} \mathrm{CAE} / \mathrm{g} \text { DDM })\end{array}$ & $71.7 \pm 0.5^{\mathrm{a}}$ & n.d. & $57.4 \pm 1.5^{\mathrm{b}}$ & n.d. \\
\hline
\end{tabular}

\#Values are mean \pm SD $(n=3)$. Values followed by same superscript letters are not significantly different, $\mathrm{p} \leq 0.05$.

* TCAD: total caffeic acid derivatives in SFM, expressed in $\mu$ mol CAE/g DDM. CAE: caffeic acid equivalents. DDM: defatted dry matter. 
Table 3. Phenolic content of Non-Industrial and Industrial RSM" .

\begin{tabular}{lllll}
\hline & $\begin{array}{l}\text { NI-RSM } \\
\text { Before alkaline } \\
\text { hydrolysis }\end{array}$ & $\begin{array}{l}\text { After alkaline } \\
\text { hydrolysis }\end{array}$ & $\begin{array}{l}\text { I-RSM } \\
\text { Before alkaline } \\
\text { hydrolysis }\end{array}$ & $\begin{array}{l}\text { After alkaline } \\
\text { hydrolysis }\end{array}$ \\
\hline $\begin{array}{l}\text { Sinapine } \\
(\mu \text { mol SAE/g DDM) }\end{array}$ & $31.7 \pm 0.7^{\mathrm{c}}$ & -- & $21.6 \pm 0.2^{\mathrm{d}}$ & -- \\
$\begin{array}{l}\text { Sinapic acid } \\
(\mu \mathrm{mol} / \mathrm{g} \text { DDM })\end{array}$ & $3.9 \pm 0.1^{\mathrm{e}}$ & $62.5 \pm 1.8^{\mathrm{a}}$ & $2.2 \pm 0.0^{\mathrm{f}}$ & $46.8 \pm 3.0^{\mathrm{b}}$ \\
$\begin{array}{l}\text { TSAD* } \\
(\mu \mathrm{mol} \text { SAE/g DDM) }\end{array}$ & $64.2 \pm 1.2^{\mathrm{a}}$ & $62.5 \pm 1.8^{\mathrm{a}}$ & $44.8 \pm 0.2^{\mathrm{b}}$ & $46.8 \pm 3.0^{\mathrm{b}}$ \\
$\begin{array}{l}\text { \#Values are mean } \pm \text { SD }(\mathrm{n}=3) . \text { Values followed by same superscript letters are not significantly } \\
\text { different, } \leq 0.05 .\end{array}$ \\
* TSAD: total sinapic acid derivatives in RSM, expressed in $\mu$ mol SAE/g DDM. SAE: sinapic \\
acid equivalents. DDM: defatted dry matter.
\end{tabular}


Table 4. Concentration of caffeic acid (CA), CAEsters and total caffeic acid derivatives (TCAD) before and after hydrolysis of NI-SFM methanolic extract with AnFaeB and ChlE at $50^{\circ} \mathrm{C}^{\#}$.

\begin{tabular}{|c|c|c|c|}
\hline & $\begin{array}{l}\text { Initial content in } \\
\text { the meal }\end{array}$ & AnFaeB & ChlE \\
\hline $\begin{array}{l}\text { 4- and 5-CQA } \\
(\mu \mathrm{mol} C A E / g \text { DDM) }\end{array}$ & $55.8 \pm 0.9^{c}$ & -- & $2.0 \pm 0.1^{\mathrm{h}}$ \\
\hline $\begin{array}{l}\text { 3-CQA } \\
(\mu \mathrm{mol} \mathrm{CAE} / \mathrm{g} \mathrm{DDM})\end{array}$ & $8.9 \pm 0.4^{\mathrm{e}}$ & -- & $7.8 \pm 0.1^{\mathrm{f}}$ \\
\hline $\begin{array}{l}\text { 3,5-di-CQA } \\
(\mu \mathrm{mol} \text { CAE/g DDM) }\end{array}$ & $4.0 \pm 0.2^{\mathrm{g}}$ & -- & $0.6 \pm 0.0^{j}$ \\
\hline $\begin{array}{l}\text { 4,5-di-CQA } \\
(\mu \mathrm{mol} \mathrm{CAE} / \mathrm{g} \mathrm{DDM})\end{array}$ & $1.8 \pm 0.1^{\mathrm{g}}$ & -- & -- \\
\hline $\begin{array}{l}\text { CA } \\
(\mu \mathrm{mol} / \mathrm{g} \mathrm{DDM})\end{array}$ & $1.2 \pm 0.0^{\mathrm{i}}$ & $68.1 \pm 1.7^{\mathrm{ab}}$ & $55.4 \pm 0.3^{\mathrm{cd}}$ \\
\hline $\begin{array}{l}\mathrm{TCAD}^{*} \\
(\mu \mathrm{mol} \mathrm{CAE} / \mathrm{g} \mathrm{DDM})\end{array}$ & $71.7 \pm 0.5^{\mathrm{a}}$ & $68.1 \pm 1.7^{\mathrm{ab}}$ & $65.8 \pm 0.4^{b}$ \\
\hline $\begin{array}{l}\text { CA yield }(\%) \text { based on } \\
\text { initial TCAD in meal }\end{array}$ & -- & 95.0 & 77.2 \\
\hline $\begin{array}{l}\text { CA yield }(\%) \text { based on } \\
\text { TCAD at } t=0 \text { of enzyme } \\
\text { incubation }^{\S}\end{array}$ & -- & 100.4 & 84.2 \\
\hline
\end{tabular}

* TCAD: total caffeic acid derivatives; CAE: caffeic acid equivalent. DDM: defatted dry matter. Values are mean $\pm S D(n=2)$. Values followed by same superscript letters are not significantly different, $\mathrm{p} \leq 0.05$.

\# 10 min incubation for AnFaeB, 60 min incubation for ChlE.

$\S$ The substrate was pre-incubated for $30 \mathrm{~min}$ in MOPS buffer before adding enzyme $(\mathrm{t}=0$ of enzyme incubation). 
Table 5. Maximal amount and yield of sinapic acid (SA) after enzymatic treatment of NIRSM and the corresponding methanolic extract with AnFaeA.

\begin{tabular}{lccc}
\hline & $\begin{array}{c}\text { NI-RSM } \\
55^{\circ} \mathrm{C}\end{array}$ & $\begin{array}{c}\text { NI-RSM } \\
\text { methanolic } \\
\text { extract, } \\
55^{\circ} \mathrm{C}\end{array}$ & $\begin{array}{c}\text { NI-RSM } \\
\text { methanolic } \\
\text { extract, } \\
37^{\circ} \mathrm{C}\end{array}$ \\
\hline $\begin{array}{l}\text { TSAD* at } \mathrm{t}=0 \text { of enzyme incubation }^{\S} \\
(\mu \mathrm{mol} \text { SAE/g DDM })\end{array}$ & $53.1 \pm 1.0^{\mathrm{c}}$ & $59.2 \pm 2.3^{\mathrm{b}}$ & $65.6 \pm 2.3^{\mathrm{a}}$ \\
$\begin{array}{l}\text { Maximum SA released after 240 min } \\
\text { incubation with enzyme }(\mu \mathrm{mol} / \mathrm{g} \text { DDM) }\end{array}$ & $41.3 \pm 0.3^{\mathrm{d}}$ & $32.3 \pm 0.4^{\mathrm{e}}$ & $30.6 \pm 1.2^{\mathrm{e}}$ \\
$\begin{array}{l}\text { SA yield }(\%) \text { based on initial TSAD in } \\
\text { meal }\end{array}$ & 64.3 & 50.3 & 47.7 \\
$\begin{array}{l}\text { SA yield }(\%) \text { based on TSAD at } \mathrm{t}=0 \text { of } \\
\text { enzyme incubation }\end{array}$ & 77.7 & 54.6 & 46.6 \\
\hline
\end{tabular}

* TSAD: total sinapic acid derivatives; SAE: sinapic acid equivalent. DDM: defatted dry matter. Values are mean \pm SD $(n=2)$. Values followed by same superscript letters are not significantly different, $\mathrm{p} \leq 0.05$

$\S$ The substrate was pre-incubated for $30 \mathrm{~min}$ in MOPS buffer before adding enzyme $(\mathrm{t}=0$ of enzyme incubation). 
Manuscript

Fig. 1

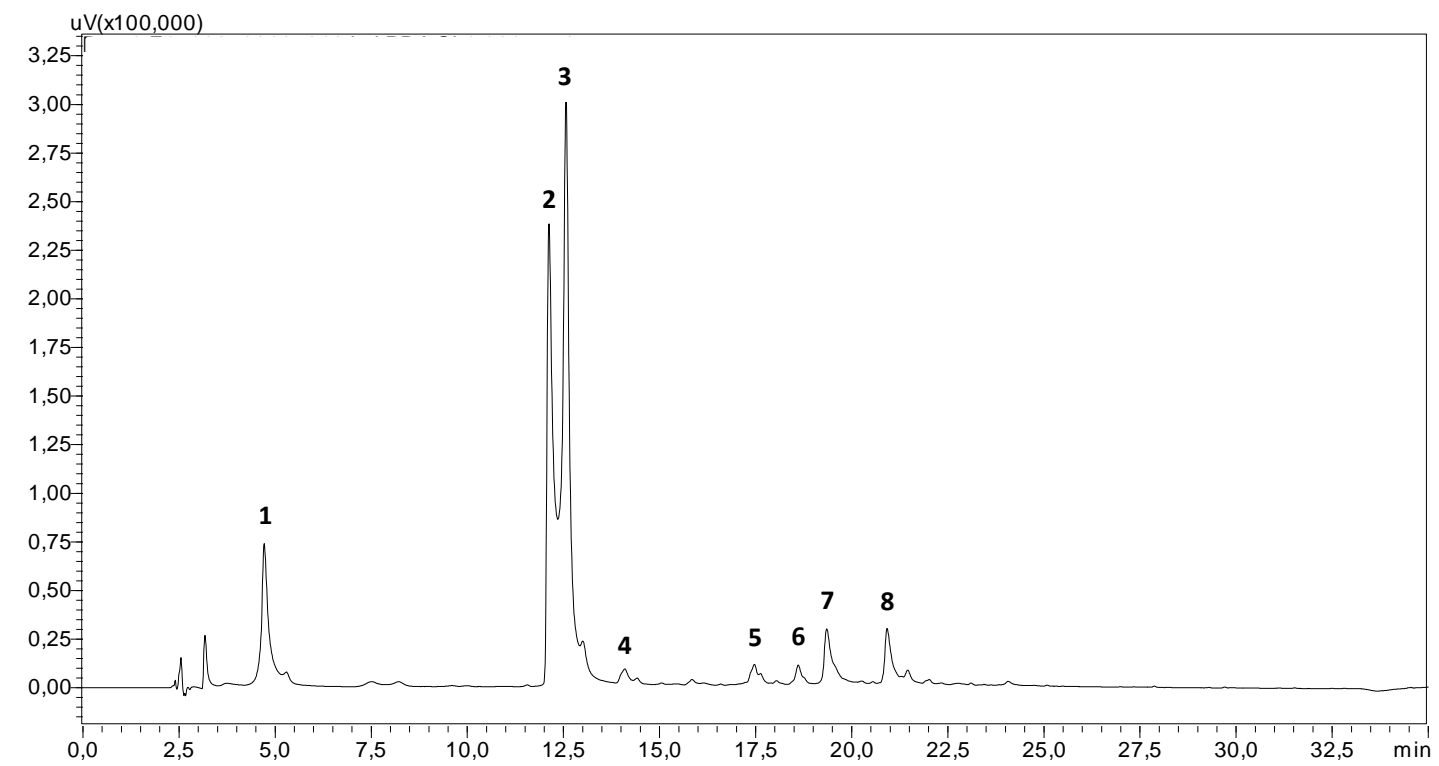


Fig. 2
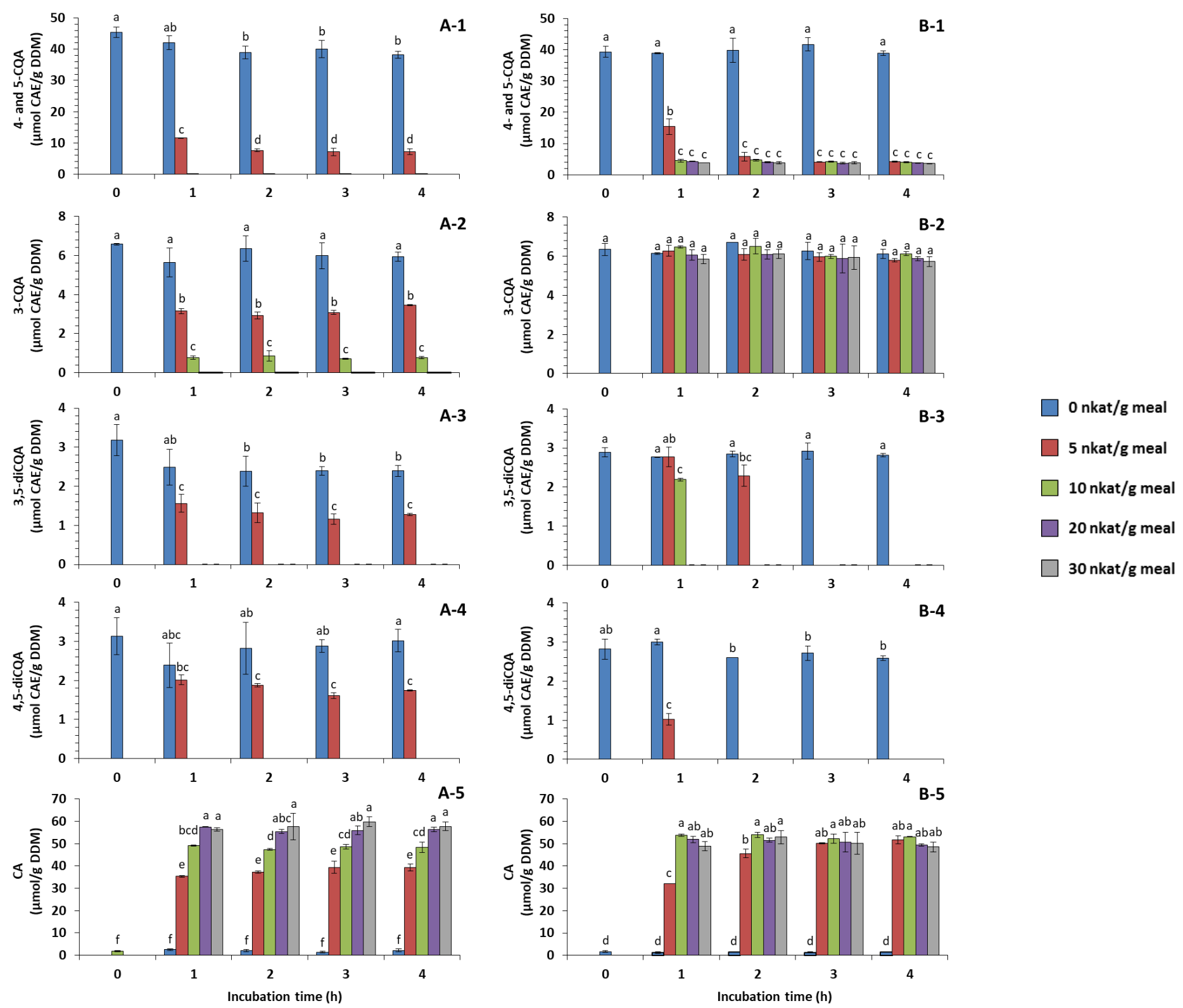
Fig. 3

4- and 5-CQA $\square$ CA $\square$ TCAD with enzyme $\square$ TCAD without enzyme (control)
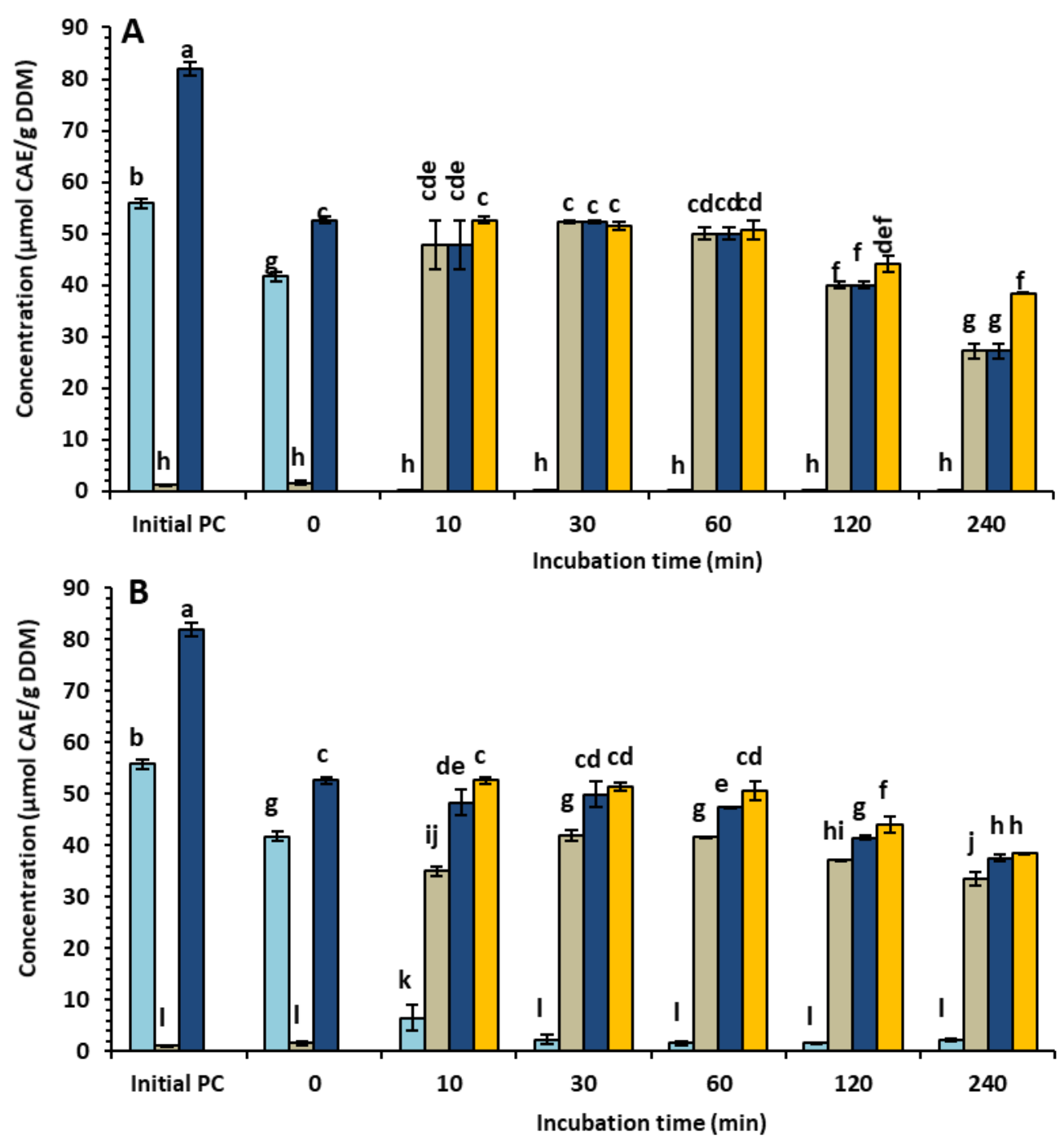
Fig. 4
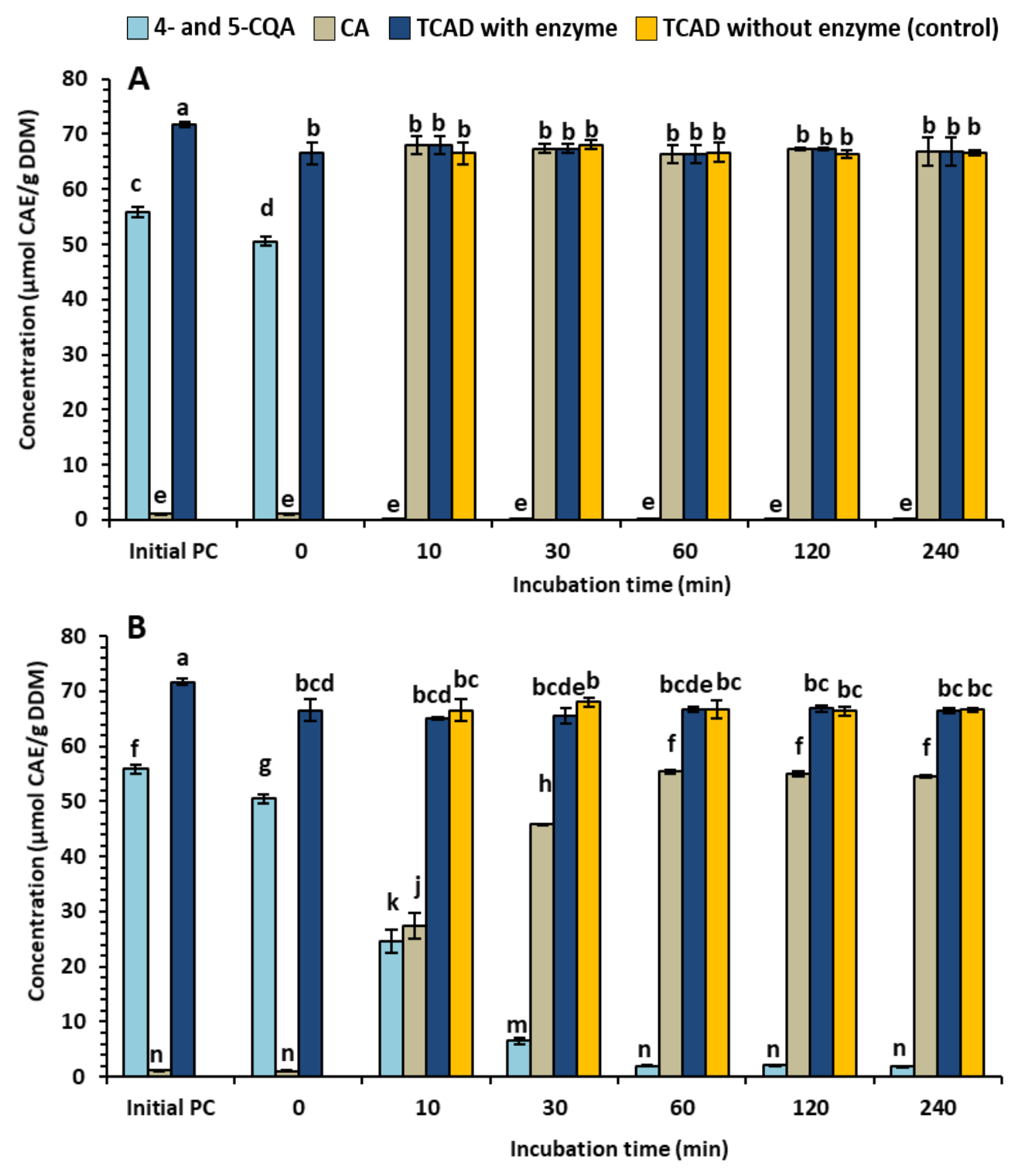
Manuscript

Fig. 5

$\square$ SNP $\square$ SA $\square$ 1,2-diSG $\square$ TSAD with enzyme $\square$ TSAD without enzyme (control)
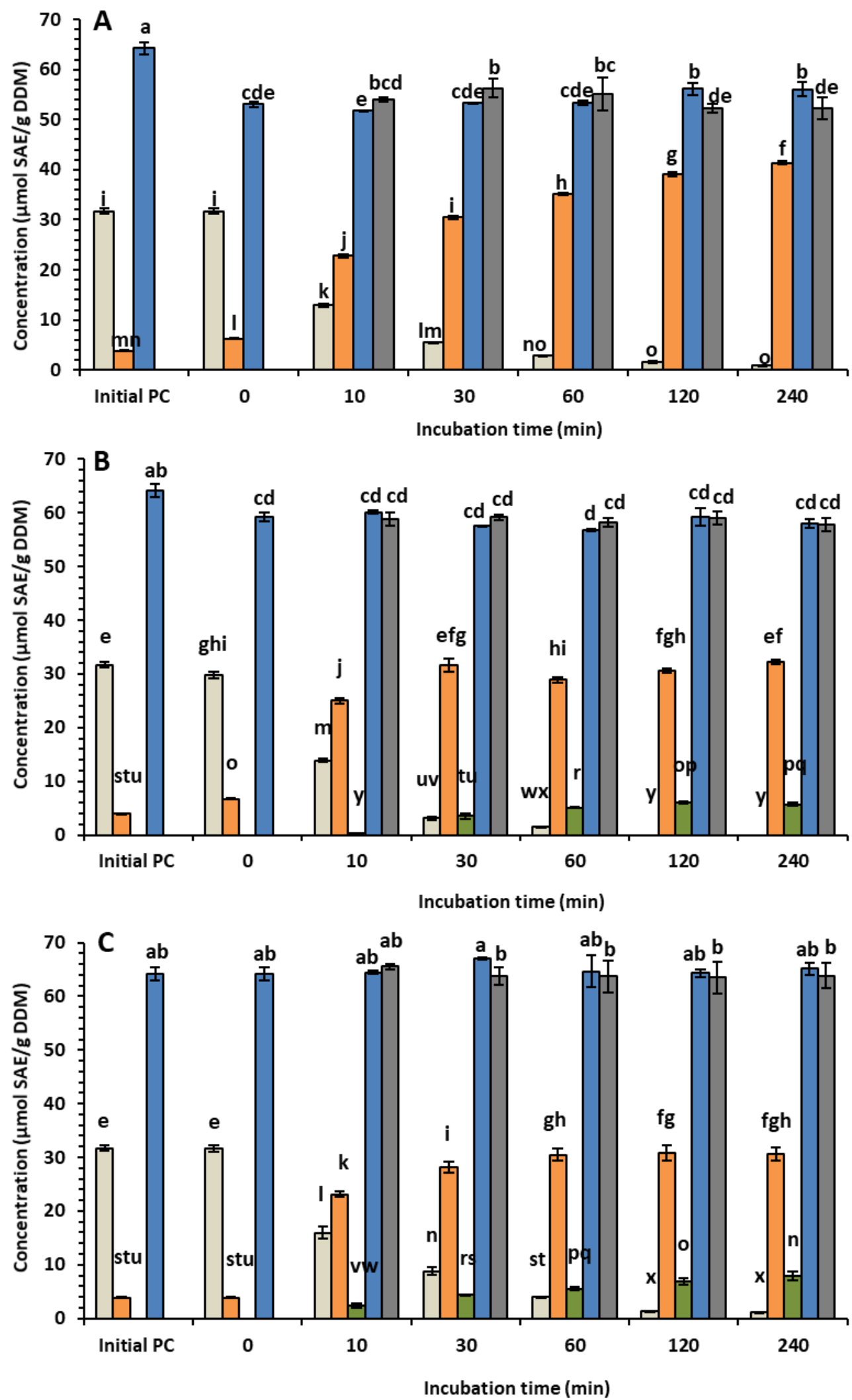


\section{Supplementary data. Fig. S1}
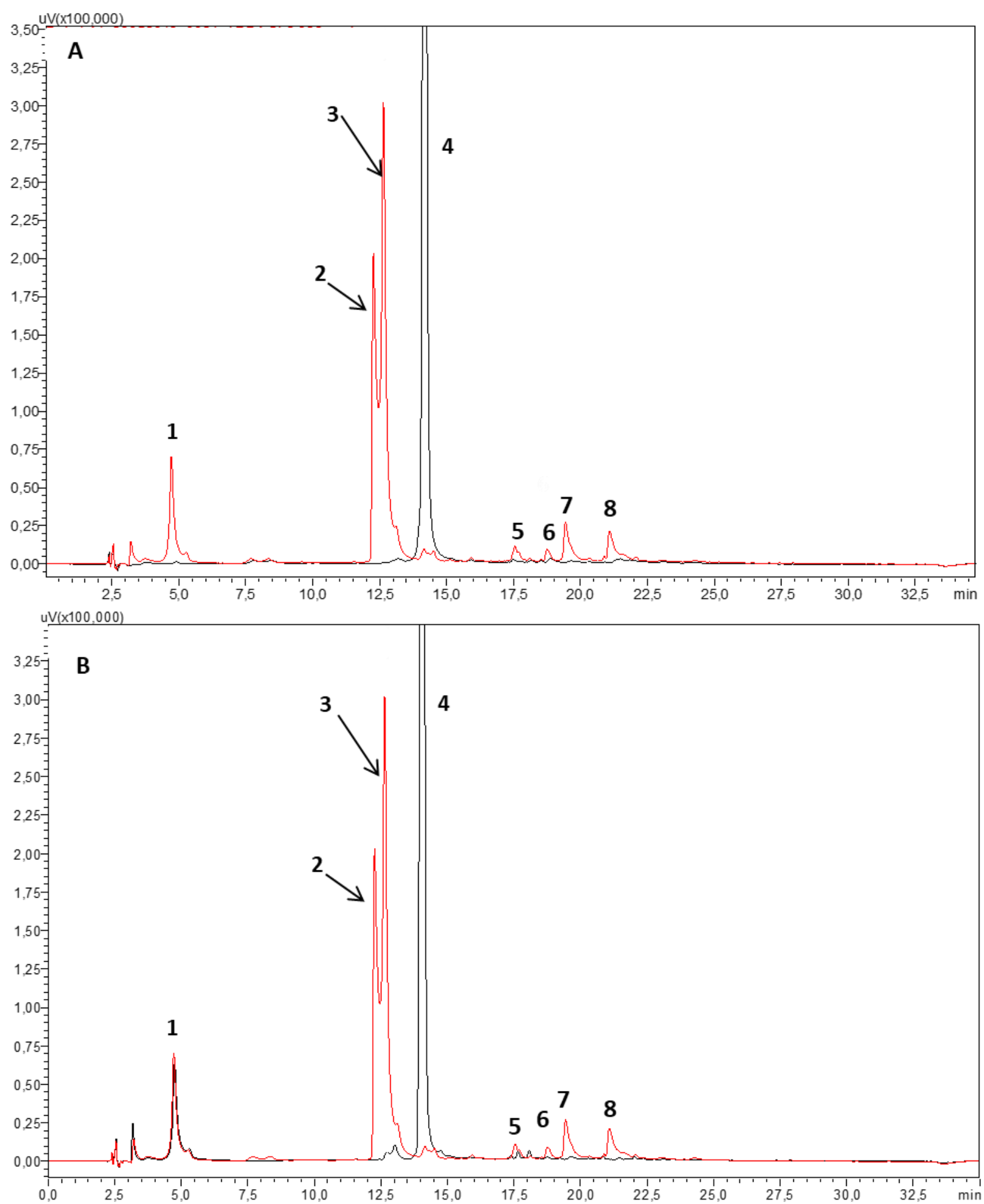
Supplementary data. Fig. S2

$$
\text { 3-CQA } \square \text { 3,5-diCQA } \square \text { 4,5-diCQA }
$$
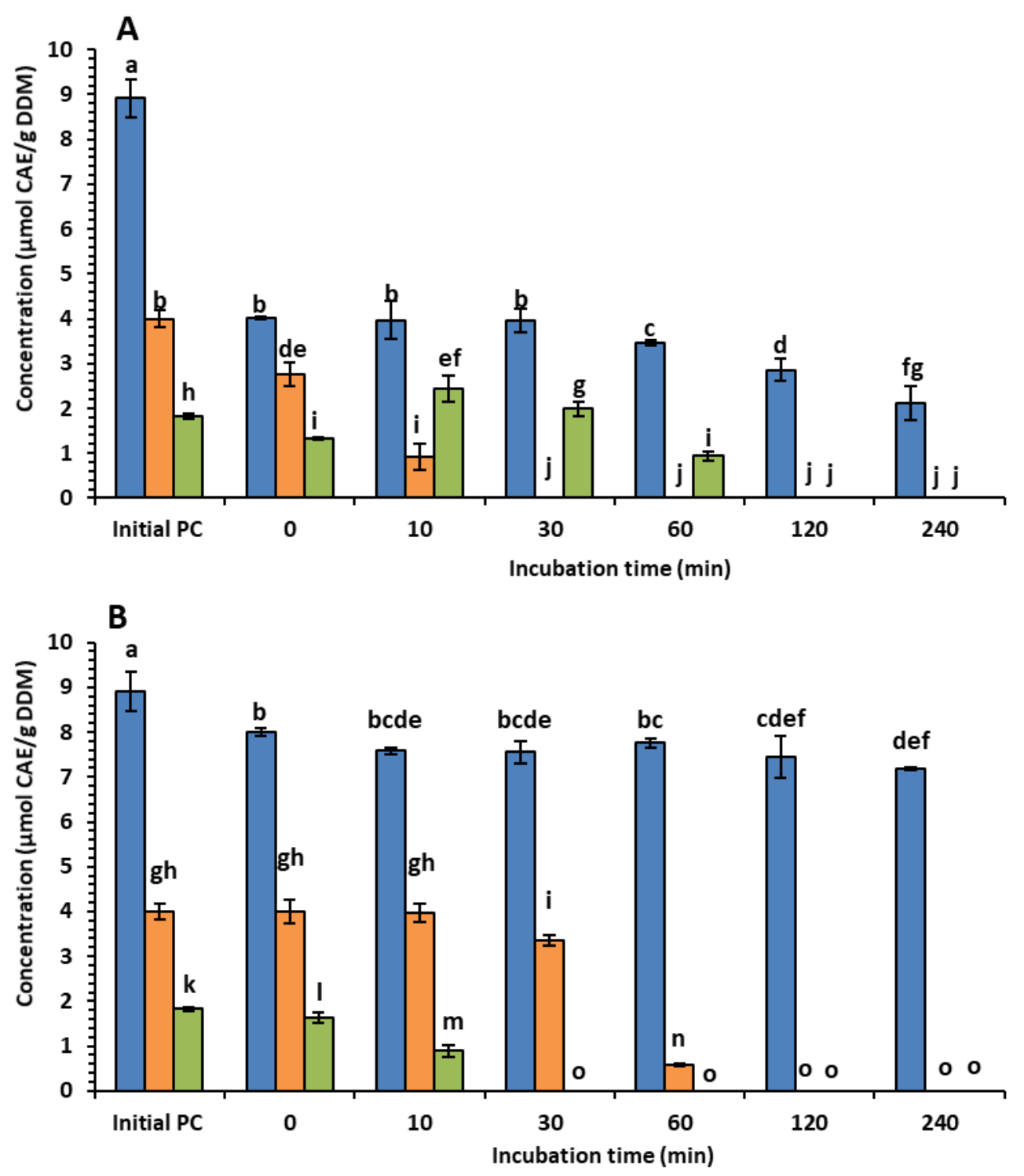
Supplementary data. Fig. S3

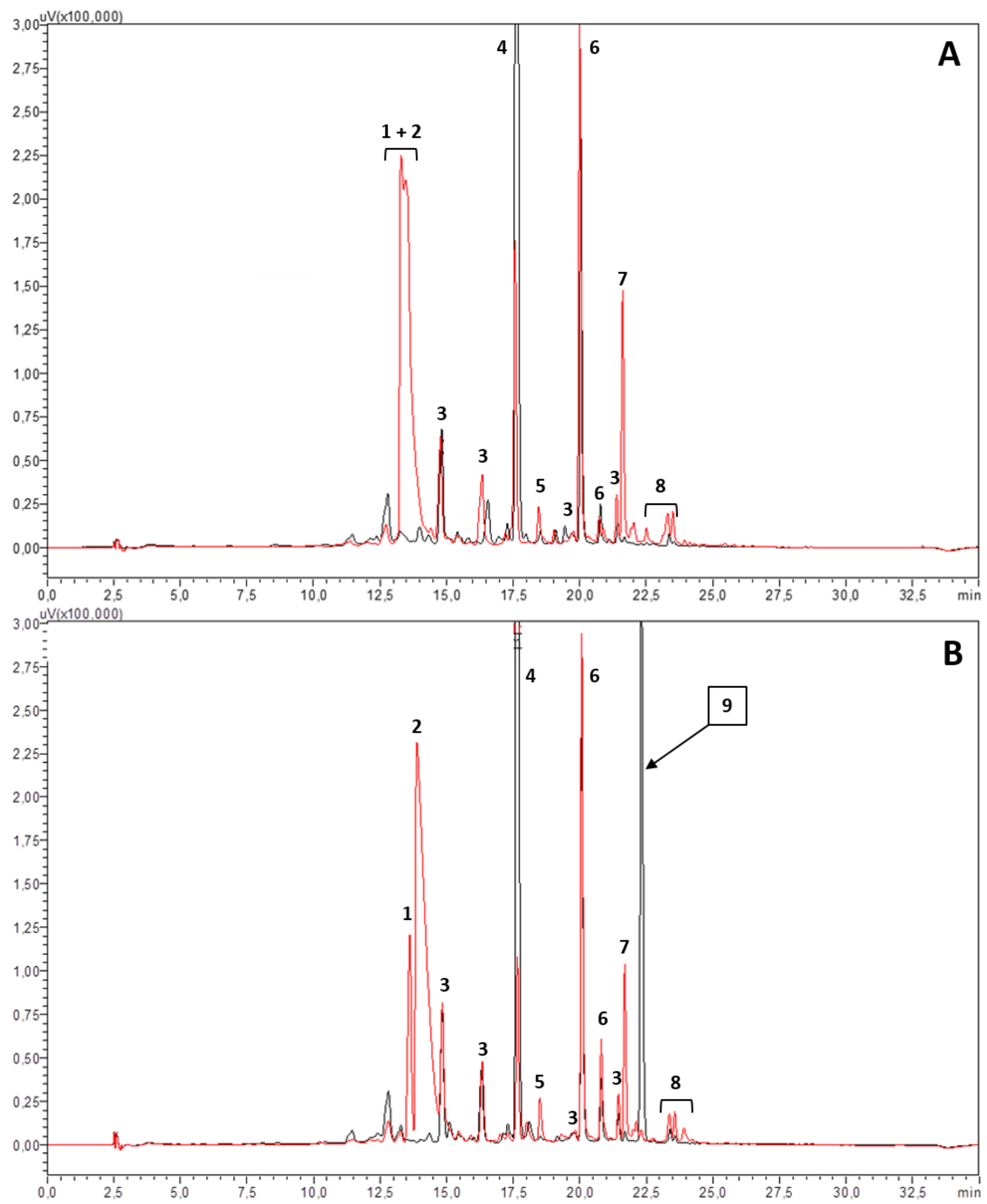




\section{Supplementary data. Fig. S4}<smiles>COc1cc(C=CC(=O)O[C@H]2O[C@H](CO)[C@@H](O)C(O)[C@H]2OC(=O)C=Cc2cc(OC)c(O)c(OC)c2)cc(OC)c1O</smiles>

\begin{tabular}{ccccc}
\hline $\mathrm{n}^{\circ}$ & $(\delta / \mathrm{ppm}){ }^{13} \mathrm{C}$ & type & $(\delta / \mathrm{ppm})^{1} \mathrm{H}$ & Multiplicity \\
\hline 1 & 92.0 & $\mathrm{CH}$ & 5.76 & $\mathrm{~d}^{*}, J=8.4 \mathrm{~Hz}$ \\
2 & 72.7 & $\mathrm{CH}$ & 4.90 & $\mathrm{dd}^{*}, J=8.4,9.2 \mathrm{~Hz}$ \\
3 & 74.1 & $\mathrm{CH}$ & 3.57 & $\mathrm{t}^{*}, J=9.2 \mathrm{~Hz}$ \\
4 & 69.8 & $\mathrm{CH}$ & 3.31 & $\mathrm{~m} *$ \\
5 & 78.1 & $\mathrm{CH}$ & 3.40 & $\mathrm{~m}$ \\
& & & 3.71 & $\mathrm{~m}$ \\
6 & 60.4 & $\mathrm{CH} 2$ & 3.52 & $\mathrm{dd}, J=5.4,12.0 \mathrm{~Hz}$ \\
7 & 165.1 & $\mathrm{CO}$ & - & - \\
8 & 113.4 & $\mathrm{CH}$ & 6.47 & $\mathrm{~d}, J_{\text {trans }}=15.8 \mathrm{~Hz}$ \\
9 & 147.4 & $\mathrm{CH}$ & 7.56 & $\mathrm{~d}, J_{\text {trans }}=15.8 \mathrm{~Hz}$ \\
10 & 106.6 & $\mathrm{CH}$ & 7.00 & $\mathrm{~s} *$ \\
11 & 165.7 & $\mathrm{CO}$ & - & - \\
12 & 114.6 & $\mathrm{CH}$ & 6.52 & $\mathrm{~d}, J_{\text {trans }}=15.8 \mathrm{~Hz}$ \\
13 & 145.9 & $\mathrm{CH}$ & 7.54 & $\mathrm{~d}, J_{\text {trans }}=15.8 \mathrm{~Hz}$ \\
14 & 106.3 & $\mathrm{CH}$ & 6.98 & $\mathrm{~s}$ \\
15 & 56.2 & $\mathrm{CH} 3$ & $3.78-3.77$ & $\mathrm{~s}$ \\
\hline
\end{tabular}




\section{Supplementary data. Fig. S5}

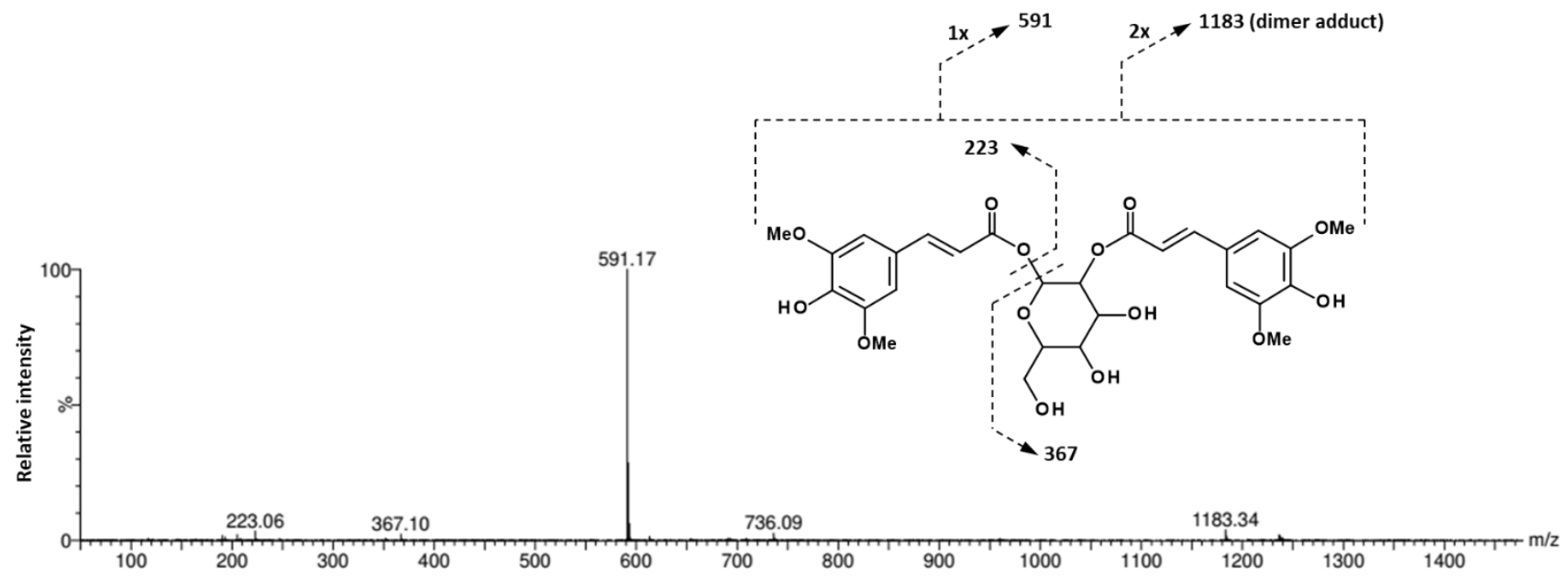

